\title{
Traumatic Brain Injury - Acute Care
}

\author{
Angela N. Hays and Abhay K. Varma \\ Medical University of South Carolina \\ USA
}

\section{Introduction}

Traumatic brain injury (TBI) is a spectrum of pathological changes in the brain that result from application of external mechanical force(s) leading to temporary or permanent impairment of neurological function. TBI is a global health problem. In 1990, 9.5 million individuals worldwide sustained a TBI severe enough to warrant medical attention or result in death (Corrigan, Selassie, \& Orman 2010). In the United States, the annual incidence of TBI is 506.4 per 100,000 population (Langlois JA 2006), in Europe it is 235 per 100,000 population (Tagliaferri et al. 2006), and in Asia it is reported to range from 160 (Gururaj G 2004) to 344 (Chiu et al. 1997) per 100,000 population (incidence rate from United States is inclusive of emergency department visits, hospital discharges and deaths, incidence rates from Europe and Asia are inclusive of hospital discharges and deaths only). Severe TBI has long term consequences for the individual and the society. In the United States, it is estimated that annually $43.1 \%(124,000)$ of the individuals discharged after acute hospitalization for TBI (Selassie et al. 2008) develop long term disability. The prevalence of individuals in the United States with disability secondary to TBI is estimated to be 3.2 million (Zaloshnja et al. 2008). The total life time cost of treating TBI cases in the United States, including loss of productivity, is estimated to be $\$ 60.4$ billion for the year 2000 (Corrigan, Selassie, \& Orman 2010).The enormous economic and social burden imposed by TBI demands aggressive measures to prevent and treat TBI.

Technological developments and better understanding of brain physiology have resulted in a dramatic improvement in mortality related to TBI. Mortality rates declined precipitously between 1970 and 1990, likely related to the routine use of computed tomography (CT) scans and intracranial pressure (ICP) monitoring, as well as improvement in trauma resuscitation generally. However, despite more recent advances in neuromonitoring and neuroimaging, mortality has remained steady at approximately 35\% since the 1990s (Stein et al. 2010). The reasons for this lack of progress are multifactorial; no doubt the increase in severe TBI among the elderly is a contributing factor (Colantonio et al. 2008). Nevertheless, the field of neurotrauma has suffered from the lack of well organized multicenter, randomized clinical trials designed to assess the efficacy of the newer techniques and interventions for the management of TBI. Efforts to design and conduct clinical trials in TBI have been challenging for many reasons including the heterogeneity of the disease, barriers to recruitment, and lack of standardized management protocols across centers (Narayan et al. 2002). This chapter presents an overview of the pathophysiology and basic principals of management of TBI, and the challenges facing the scientific community in dealing with this debilitating disorder. 


\section{Mechanism}

TBI results from the application of external force to cranium and its contents. The severity of injury is determined by the nature, magnitude and duration of load applied to cranium and the force vector (rotational, translational or angular) (Gennarelli 1993). Force applied to cranium can be static (delivered over more than 200 milliseconds) or dynamic (delivered over less than 200 milliseconds). Static loading is a less common cause of TBI in clinical situations, and usually leads to focal brain damage. Dynamic loading is a more common cause of TBI, and produces more complex and widespread brain damage. Dynamic loading itself results from direct blow to the cranium (contact load), or rapid acceleration or deceleration of the cranium (inertial load) that causes differential motion of the brain relative to the skull. Inertial loading can cause translational movement (linear motion of brain in the skull), rotational movement (shearing motion of different layers of brain in relation to one another), and angular movement (a combination of translational and rotational movements). In most clinical situations, severe TBI is initiated by impact to the head of a solid object at a high velocity, leading to brain damage by a combination of contact and inertial loading (Graham, Adams, \& Gennarelli 1988).

Traumatic brain injury can be focal or diffuse. Focal injury manifests as fractures, contusion or hematoma with mass effect. Contact loading, wherein a significant force is applied to cranium, can cause fracture at the site of impact with underlying contusion or epidural/subdural hematoma. If contact loading also produces translational acceleration or deceleration of the brain within the cranium, it can also cause focal damage by compression of brain under the site of impact (coup contusion) or remote from it (counter coup contusion). Diffuse brain injury results from rotational or angular acceleration or deceleration of the brain; the presentation can vary from transient loss of consciousness (concussion) to diffuse axonal injury (DAI) with prolonged coma. With increasing magnitude of inertial force progressively deeper structures in the brain suffer DAI (Adams et al. 1989). In clinical situations focal lesions and DAI frequently coexist (Skandsen et al. 2010).

\section{Pathophysiology}

TBI is not a static event, but a constantly evolving dynamic process. The initial insult leads to instant brain damage known as primary brain injury. Primary brain injury triggers a cascade of events that cause brain edema, intracranial hypertension, and consequent ischemia, categorized as secondary brain damage (Enriquez \& Bullock 2004). In diffuse injury the primary insult is at the cellular level and initiates events that lead to release of excitatory neurotransmitters, loss of ionic homeostasis, disruption of ATP production, toxicity from free radical production, loss of auto regulation and breakdown of blood brain barrier (BBB). These pathological changes lead to secondary injury. Similar secondary changes also occur in the region surrounding an area of contusion or traumatic hematoma, with a zone of ischemia and swelling developing around the focal injury. Tissue in this "ischemic penumbra" is at risk of dying but also salvageable (Schroder et al. 1995; Leker \& Shohami 2002). Treatment of acute TBI is directed at minimizing secondary brain damage that follows focal as well as diffuse TBI.

A good understanding of cellular and biochemical changes that follow brain trauma is required for the optimal management of brain injury, and for directing future research aimed at design of new therapies and protocols. A detailed discussion of these changes is 
beyond the scope of this chapter; however, a brief summary is presented. Following trauma, the excitatory amino acid glutamate is released from the presynaptic neurons and activates both post synaptic neurons and glial cells. Under physiological conditions both glial cells and postsynaptic neurons actively remove glutamate from the synaptic space. Following trauma the high levels of glutamate activate receptors in the cell membranes of postsynaptic neurons and glial cells, resulting in $\mathrm{Ca}^{2+}$ influx into the cell with consequent free radical formation and increased oxidative stress. Calcium ions also accumulate in the mitochondria leading to mitochondrial membrane damage and disruption of energy cycle. These events eventually trigger necrosis and apoptosis in the cells (Enriquez \& Bullock 2004; Shohami et al. 1997).

TBI disrupts the BBB that allows fluid to move from intravascular compartment to extravascular compartment in the brain with resultant brain swelling and intracranial hypertension, which in turn leads to fall in cerebral perfusion thus further exacerbating brain ischemia. Aquaporins, matrix metalloproteinases and vasoactive inflammatory agents are potential mediators of BBB breakdown following trauma (Donkin \& Vink 2010). A porous BBB allows infiltration of inflammatory cells into damaged brain. These cells (neutrophils and macrophages) release free radicals and cytokines into the brain tissue accentuating the damage (Soares et al. 1995).

\section{Initial management at the scene of injury}

Pre-hospital management is a critical step in the overall care of acute brain injury. Early institution of optimal care will minimize secondary injury while the patient is transported to a tertiary care facility. About half the deaths following TBI occur within first 2 hours of the injury (Badjatia, Carney et al. 2008) thereby signifying the importance of optimal prehospital care.

Pillars of pre-hospital care are restoring and maintaining airway, breathing and circulation (ABC) (Dewall 2010). The cervical spine must be immobilized as the patient is resuscitated, and spine precautions should be maintained till the patient is transferred to a trauma center. Intubation is indicated to secure the airway if the Glasgow Coma Scale (GCS) is less than 9, if the patient is hypoxic $\left(\mathrm{SpO}_{2}<90 \%\right)$ despite supplemental oxygen, or if the patient is unable to maintain a patent airway (Gabriel et al. 2002). The $\mathrm{SpO}_{2}$ should be kept above $95 \%$, while maintaining eucapnea with an end tidal carbon dioxide $\left(\mathrm{EtCO}_{2}\right)$ of 35 to $40 \mathrm{~mm}$ $\mathrm{Hg}$ (Badjatia, Carney et al. 2008). Hypotension accelerates secondary injury, and must be promptly recognized and treated. Systolic blood pressure below $90 \mathrm{~mm} \mathrm{Hg}$ has been shown to increase mortality by two fold in TBI (Chesnut et al. 1993). Intravenous access should be promptly established, and normal saline is a reasonable choice for pre hospital fluid resuscitation (Dewall 2010). Intravenous dextrose should be administered only if blood glucose is less than $70 \mathrm{mg} / \mathrm{dl}$ (Badjatia, Carney et al. 2008). Persistent hypotension should prompt search for extracranial injury or spinal cord injury. Neurogenic hypotension presents with bradycardia and hypotension as opposed to hypovolemic shock that is characterized by tachycardia and hypotension.

Glasgow coma scale (GCS) and pupillary response should be documented after the ABCs of resuscitation are complete, and if more than one provider is available, this can be done while the ABCs are being secured. Assessment of the GCS and pupillary response in prehospital setting allows the emergency medical personnel to communicate to the receiving hospital the neurological status of the patient, screen for cerebral herniation and trend the 
neurological status (Badjatia, Carney et al. 2008). A quick secondary survey for extracranial injuries should be performed prior to transport (Dewall 2010).

Timely transport of these patients to tertiary care center is critical to a favorable outcome. Patients with severe TBI (GCS < 9) should be transported directly to a facility equipped with an immediately available CT scanner, prompt neurosurgical care and the ability to monitor intracranial pressure and treat intracranial hypertension (Badjatia, Carney et al. 2008), even if it is not the closest hospital (Hartl et al. 2006). Mortality can increase by $50 \%$, if a severe TBI patient is not directly transported to such a facility (Hartl et al. 2006). Mode of transport (by road or air) should be chosen to minimize the transit time (Dewall 2010), as mortality following acute subdural hematoma has been shown to be directly linked to time to surgical intervention (Seelig et al. 1981).

\section{Medical management}

\subsection{Principles of intensive care}

Management of the patient with traumatic brain injury is directed predominantly at minimizing and preventing secondary brain injury, which can result from intracranial or systemic causes. Although the mechanisms of secondary brain injury are incompletely understood, inadequate cerebral perfusion and oxygenation are integral factors. Systemic hypoxia and hypotension are significantly associated with increased morbidity and mortality. This effect was demonstrated in a data set from the Traumatic Coma Data Bank, in which a single episode of systemic hypotension was associated with double the risk of death (Chesnut et al. 1993; Bratton et al. 2007). This observation serves to demonstrate that good basic critical care is paramount. Current guidelines recommend a systolic blood pressure greater than $90 \mathrm{mmHg}$ as a resuscitation end-point (Bratton et al. 2007). Adequate fluid resuscitation is important, but vasopressors should be used if fluids are insufficient to maintain adequate systemic blood pressures. Intubation and mechanical ventilation are necessary for patients presenting with severe brain injuries in order to ensure adequate oxygenation and ventilation, and to minimize the risk of aspiration (Valadka \& Robertson 2007). Admission to a dedicated neuroscience critical care unit, when available, may also result in improved outcomes (Patel et al. 2005).

Ventilator management in patients with severe TBI presents some unique challenges because of the effect of $\mathrm{PaCO}_{2}$ on cerebrovascular autoregulation. Hyperventilation has long been recognized as an effective means for treating acutely elevated intracranial pressure. Hyperventilation results in a systemic respiratory alkalosis, which in turn lowers the $\mathrm{pH}$ of the cerebrospinal fluid. In patients with intact cerebral autoregulation, this change in $\mathrm{pH}$ results in constriction of cerebral arterioles, thereby decreasing the cerebral blood volume and lowering the intracranial pressure. As a result of this phenomenon, routine hyperventilation of TBI patients has been advocated in the past. However, experimental evidence has demonstrated that the vasoconstrictive effect is relatively short-lived, (Muizelaar et al. 1988) and there is concern that continued hyperventilation could potentiate cerebral ischemia (Bratton et al. 2007). Furthermore, subsequent efforts to correct an iatrogenic respiratory alkalosis sometimes precipitate rebound increases in intracranial pressure (Valadka \& Robertson 2007). For these reasons, hyperventilation is usually employed only as a temporizing measure in patients suffering an acute neurological decline. The relationship between $\mathrm{PaCO}_{2}$ and cerebral blood flow becomes particularly problematic in TBI patients with co-morbid lung injury. Acute lung injury (ALI) and acute respiratory distress syndrome (ARDS) are not uncommon in the neurological critical care unit. Since the 
publication of the ARDSnet trial in 2000, the mainstay of therapy for patients with ALI and ARDS has been lung-protective ventilation, which minimizes barotrauma to the lungs by employing lower tidal volumes ( The Acute Respiratory Distress Syndrome Network 2000). This strategy results in a moderate degree of hypercapnea and hypoxemia. While lungprotective ventilation significantly improved mortality in the study population, the relative hypercarbia and hypoxemia may have deleterious effects in a patient who is at risk for cerebral edema, ischemia, or vasospasm. Randomized trials in TBI patients with ARDS are lacking. Monitoring of cerebral perfusion and oxygenation, which is discussed in subsequent sections, is particularly crucial in this scenario (Young et al. 2010).

Because of the brain's role in regulating metabolism, patients with severe traumatic brain injury demonstrate a number of metabolic derangements which ultimately result in systemic catabolism (Cook, Peppard, \& Magnuson 2008). Adequate nutritional support is essential to forestall adverse consequences, including protein loss and immunocompromise (Sacks et al. 1995). Early institution of nutritional support has a significant impact on mortality and decreases the rate of hospital-acquired infections (Hartl et al. 2008; Taylor et al. 1999). Patients with severe TBI will require replacement of approximately $140 \%$ of their resting energy expenditure, though this requirement will be decreased somewhat in the setting of pharmacological paralysis or deep sedation. Protein requirements are estimated at about 1.5-2 grams/kg of protein (Cook, Peppard, \& Magnuson 2008). Close monitoring is essential to ensure adequate supplementation and avoid complications such as hyperglycemia. Early hyperglycemia has been associated with poor outcome in TBI patients (Liu-DeRyke et al. 2009), but intensive glycemic control may exacerbate metabolic stress in some patients (Vespa et al. 2006). Although the optimal glucose range for TBI patients has yet to be determined, our institution has chosen $140-180 \mathrm{mg} / \mathrm{dL}$ as a reasonable target range.

Because of their increased sympathetic tone, severity of illness, and degree of immobility, TBI patients are at high risk of complications of critical illness including infection and thromboembolism. Long-term use of prophylactic antibiotics is discouraged, though there is some evidence that brief treatment at the time of endotracheal intubation reduces the incidence of ventilator-associated pneumonia (Sirvent et al. 1997). Fevers are common in patients with traumatic brain injury, and may represent an underlying infection, hypothalamic dysfunction, or other non-infectious cause. Hyperpyrexia must be investigated exhaustively in order to rule out the possibility of an infectious etiology; however, any fever in a patient with neurological injury must be treated aggressively. Increased temperature results in increased cerebral blood flow, which can exacerbate intracranial hypertension and reduce intracranial compliance (Segatore 1992). Furthermore, animal studies have indicated that hyperthermia can increase infarct size and potentiate cellular damage (Dietrich et al. 1996; Dietrich \& Bramlett 2007). For these reasons, aggressive treatment of fever in brain-injured patients is warranted. First-line treatments generally include antipyretics such as acetaminophen; cooling blankets, fans, and chilled fluids have also been employed (Johnston et al. 2006). Control of shivering is also important, as shivering can increase metabolic demand and impede efforts to maintain normothermia (Badjatia, Strongilis et al. 2008).

Prevention of thromboembolic events is a major consideration in patients with severe TBI, especially in poly-trauma patients. Mechanical prophylaxis with graduated compression stockings and/or pneumatic compression devices is recommended, though these interventions may be contraindicated in the presence of significant injury to the lower extremities (Bratton et al. 2007). Pharmacological prophylaxis with unfractionated (UH) or 
low-molecular weight heparin (LMWH) has been the subject of some debate. There is concern that use of pharmacological interventions could result in exacerbation of cerebral contusions, intracranial hemorrhage, and systemic bleeding. Evidence in a neurosurgical population indicates that pharmacological prophylaxis used in conjunction with mechanical devices is more effective than mechanical measures alone (Nurmohamed et al. 1996; Agnelli et al. 1998). Recent observational evidence suggests that initiation of prophylactic treatment with LMWH within 48 hours of injury or neurosurgical intervention is effective and associated with an acceptably low risk of complications (Norwood et al. 2008; Dudley et al. 2010). Unfortunately, the most effective agent and dosing strategy is yet to be determined.

\subsection{Cerebral edema, intracranial hypertension and cerebral perfusion pressure}

The components of the intracranial compartment under normal circumstances consist of brain tissue, cerebrospinal fluid, and blood. Because the intracranial contents are contained within the rigid confines of the skull, any increase in volume - in the form of cerebral edema or a pathological mass lesion-must be met with a compensatory decrease in one of the other components, or the ICP will rise. Elevated ICP can result in cerebral ischemia, an important cause of secondary brain injury, by reducing cerebral perfusion pressure $(\mathrm{CPP})$ :

$$
\mathrm{CPP}=\mathrm{MAP}-\mathrm{ICP}
$$

Where MAP is the mean arterial pressure.

There is a considerable amount of debate regarding the relative importance of CPP and ICP thresholds. On one hand, observational data indicates that ICP $>20 \mathrm{mmHg}$ is an independent predictor of morbidity and mortality (Helmy, Vizcaychipi, \& Gupta 2007; Valadka \& Robertson 2007; Robertson et al. 1999; Hiler et al. 2006; Czosnyka et al. 2005); however, good outcomes are possible even in the setting of exceptionally high ICPs, provided that cerebral perfusion is maintained. As a consequence, some centers advocate a CPP guided strategy, where as other clinical protocols focus predominantly on ICP and minimization of cerebral edema (Eker et al. 1998). Guidelines recommend ICP monitoring in patients with a Glasgow Coma Score (GCS) $\leq 8$ who have abnormalities visible on computed tomography $(\mathrm{CT})$. In the absence of $\mathrm{CT}$ abnormalities, ICP monitoring is indicated in comatose patients meeting 2 of the following criteria: age $>40$ years, presence of motor posturing on exam, and/or SBP $<90 \mathrm{mmHg}$ (Bratton et al. 2007). ICP values in excess of 20 $\mathrm{mmHg}$ are considered pathological, though it is important to note that herniation can occur at lower ICPs, especially in the presence of intracranial mass lesions (Bratton et al. 2007).

The situation is complicated by the fact that the relationship between ICP and CPP is affected by the integrity of cerebrovascular autoregulatory mechanisms. When cerebral autoregulation is intact, a fall in CPP is met with reflex cerebral vasodilation. This can precipitate an increase in ICP, thereby further diminishing cerebral perfusion (Robertson 2001). In this setting, efforts to augment CPP artificially may abort a destructive cycle and arrest ongoing secondary brain injury. However, if CPP falls outside of the range of normal autoregulation, or if cerebral autoregulation is impaired, this relationship is reversed: ICP will rise in a linear fashion with increasing CPP, and artificial augmentation of cerebral blood flow may result in worsening cerebral edema and hyperemia. Initially, observational data using historical controls lead to the conclusion that CPP should be maintained at $>70$ $\mathrm{mmHg}$. However, in a retrospective analysis of the Selfotel trial, Juul et al. found that there was no outcome benefit obtained by maintaining CPP $>60$; interestingly, ICP $\geq 20$ was the 
most powerful predictor of outcome (Juul et al. 2000). The only randomized trial to date addressing the question of CPP vs. ICP was published by Robertson, et al. in 1999. In this trial, the CPP in one group was maintained at $>70 \mathrm{mmHg}$; in the other group, the ICP was maintained at $\leq 20 \mathrm{mmHg}$ and CPPs as low as $50 \mathrm{mmHg}$ were permitted. The investigators found no significant difference in outcome, but the CPP-targeted strategy carried five times the risk of ARDS (Robertson et al. 1999). An increasing appreciation of the role of cerebrovascular autoregulation in secondary brain injury has led some investigators to incorporate assessment of autoregulatory function into clinical protocols. The most readily available measure is the pressure reactivity index (PRx), which is a moving correlation coefficient calculated from measurements of ICP and MAP (Czosnyka et al. 1998). Centers that employ this measurement have reported that patients with intact autoregulation (PRx is low) have improved outcomes when managed according to a CPP guided paradigm, whereas those with impaired autoregulation (PRx is elevated) benefit from an ICP targeted strategy (Howells et al. 2005). Clearly, this observation warrants additional study.

Interventions to control intracranial hypertension generally act to decrease the volume of one component of the intracranial compartment: blood, brain, or CSF. First line interventions include patient positioning, adequate sedation and analgesia, and maintenance of normothermia. The head of the bed should be elevated and any obstructions to jugular venous outflow, such as cervical collars, should be minimized. Adequate sedation and analgesia serve to minimize ventilator dyssynchrony, lower intrathoracic and intraabdominal pressure, and decrease agitation (Helmy, Vizcaychipi, \& Gupta 2007). Treating systemic fever can mitigate the associated CNS hyperemia prevent shivering and rigors, which often result in increased ICP. If an external ventricular drain is present, diversion of cerebrospinal fluid can be helpful as well.

Use of hyperosmolar substances is the mainstay of therapy for cerebral edema, with or without associated intracranial hypertension (Bhardwaj 2007). Infusion of a hyperosmolar substance serves to generate an osmotic gradient across the blood-brain-barrier, which reduces cerebral edema by drawing water out of the brain tissue. Mannitol and hypertonic saline (HTS) are the most commonly used agents in clinical practice. Mannitol is generally given as a bolus in doses ranging from 0.25-1.5 grams $/ \mathrm{kg}$. Hypertonic saline can be administered as a bolus or as a continuous infusion. For continuous use, concentrations ranging from $2 \%$ to $7.5 \%$ have been reported; boluses of $23.4 \% \mathrm{NaCl}$ can be used in the setting of acute neurological decline. Use of either agent can result in rapid improvement in ICP; therefore, selection of the appropriate treatment will depend upon the clinical scenario. Mannitol can easily be infused through a peripheral intravenous line, whereas concentrations of HTS $>2 \%$ require central access. Mannitol acts as an osmotic diuretic, and can result in intravascular volume depletion, hypokalemia, and hypotension. There is concern that repeated dosing can result in renal impairment, especially if the drug is not adequately cleared by the kidneys; this can be monitored by calculating the osmolal gap. Hypertonic saline, on the other hand, acts as a volume expander and has been shown to be an effective means of reducing ICP even in patients who did not respond to mannitol (Ogden, Mayer, \& E. Sander Connolly 2005; Vialet et al. 2003; Schwarz et al. 2002). Potential adverse events include congestive heart failure and hyperoncotic hemolysis; rapid administration of concentrated solutions may also result in transient hypotension. Either agent has the potential to accumulate in brain tissue in the presence of disruption of the blood-brain-barrier, Also, continued exposure to a hypertonic environment induces the generation of idiogenic osmoles within brain tissue, possibly setting the stage for rebound 
intracranial hypertension when the serum osmolarity begins to fall (Diringer \& Zazulia 2004). Consequently, close monitoring of the patients' ICP, CPP, serum sodium, and serum osmolarity is required. Despite the lack of convincing evidence, general consensus it that driving the serum sodium above $160 \mathrm{mEq} / \mathrm{L}$ is rarely beneficial, and most clinicians try to maintain the serum osmolarity below $320 \mathrm{mOsm} / \mathrm{L}$ (Hays et al. 2011).

When intracranial hypertension persists despite maximal osmotherapy, ICP may be controlled by interventions designed to decrease the cerebral blood volume. This can be accomplished by suppressing brain metabolism, either by inducing a pharmacological coma or with therapeutic hypothermia. Induction of a pharmacological coma is usually accomplished using barbiturates, such as pentobarbital. Barbiturates have been shown experimentally to mitigate the development of brain edema (Mishina \& Yabuki 1994), decrease cerebral metabolism, and lower cerebral blood flow (Kassell, Hitchon et al. 1980). Early experimental data suggested a neuroprotective effect in models of focal cerebral ischemia (Smith et al. 1974); however, subsequent small-scale clinical trials were disappointing (Ward et al. 1985; Kassell, Peerless et al. 1980). Studies in brain injured patients indicate that barbiturates may be less effective than mannitol as an initial intervention, but nevertheless are useful in patients who have failed maximal osmotherapy (Eisenberg et al. 1988; Schwartz et al. 1984; Marshall et al. 2010). Pentobarbital has a number of undesireable side-effects including systemic hypotension, decreased gastric motility, and bone marrow suppression (Meyer et al. 2010). In addition, continuous infusion of pentobarbital results in delayed drug clearance, which can delay detection of neurological improvement or decline. Continuous electroencephalography allows the clinician to titrate to burst-suppression, thereby ensuring that the minimum effective dose is employed. Several other agents, including propofol and midazolam, can be used to suppress CNS metabolism and induce burst-suppression, though they do not appear to be as effective as barbiturates in the treatment of intracranial hypertension (Meyer et al. 2010; Stewart et al. 1994). Unfortunately, no comparative trials are available.

Induced hypothermia has been investigated as a neuroprotective strategy in many disease states, and is currently the standard of care for comatose patients following cardiac arrest (Bernard \& Buist 2003; Mild therapeutic hypothermia to improve the neurologic outcome after cardiac arrest 2002; Bernard et al. 2002). Moderate hypothermia has been shown to decrease the cerebral metabolic rate considerably (Rosomoff \& Holaday 1954). In models of ischemia, it serves to decrease the concentrations of lactate and excitotoxic neurotransmitters (Illievich et al. 1994). Although clinical trials have failed to demonstrate an outcome benefit for early hypothermia in traumatic brain injury (Clifton et al. 2001), there is ample evidence that moderate hypothermia is an effective intervention for intracranial hypertension (Meyer et al. 2010). Most investigators used a target temperature between $33-35^{\circ} \mathrm{C}$, which can be achieved using a variety of cooling methods (Marion et al. 1993; Marion et al. 1997; Liu et al. 2006; Qiu et al. 2007; Jiang, Yu, \& Zhu 2000; Shiozaki et al. 1993). Complications of moderate hypothermia include an increased susceptibility to infection, cardiac arrhythmias, coagulopathy, and electrolyte disturbances. Iatrogenic hypothermia can also mask a fever, and potentially delay the diagnosis of an underlying infection; for that reason, the authors advocate following the white blood cell count and obtaining periodic cultures in all hypothermic patients. Shivering is often encountered during the induction and rewarming phases, and this can counteract the beneficial effects of hypothermia on ICP and cerebral metabolic rate. Pharmacological paralysis is often used to prevent shivering, but other interventions including magnesium, dexmedetomidine, and meperidine have also been 
used successfully (Weant et al. 2010). Many of these complications of systemic hypothermia may be mitigated by the use of selective brain cooling devices, which are employed at some institutions (Qiu et al. 2006; Liu et al. 2006).

The duration of hypothermia therapy can vary widely depending upon the clinical needs of the individual patient; reports in the literature range from 24 hours to 14 days (McIntyre et al. 2003). The rewarming phase of therapy is critical due to the risk of mitochondrial injury, vascular dysregulation, and rebound increases in ICP (Jiang, Yu, \& Zhu 2000; Jiang \& Yang 2007; Povlishock \& Wei 2009). Although the optimum rewarming rate has yet to be determined, most authors advocate rates of approximately 0.5-1\%/hour (Bernard \& Buist 2003; Bernard et al. 2002; Alzaga, Cerdan, \& Varon 2006). At our institution, cooling is generally performed for a minimum of 48 hours. If the patient's ICP remains well-controlled during that period, rewarming is initiated at a rate of approximately $0.5 \% / \mathrm{hr}$. In the event of recurrent intracranial hypertension, rewarming is halted for an additional 12-24 hours before repeating the attempt.

\subsection{Advanced neuromonitoring}

In an effort to elucidate the mechanisms of secondary brain injury in severe TBI and improve outcomes from this highly morbid condition, a number of technologies have been developed to provide information regarding brain function, oxygenation, and perfusion. Neurophysiologic techniques such as electroencephalography have been used intermittently in brain injured patients for decades; however, recent evidence suggests that continuous monitoring may provide considerable benefit. Similarly, recent technological advances have enabled the bedside assessment of cerebral perfusion and oxygenation at the bedside. These techniques will be discussed briefly in the following sections.

\subsubsection{Continuous electroencephalography}

Electroencephalography (EEG) is used for a variety of indications in brain injured patients. Continuous electroencephalography (cEEG) can be employed for the diagnosis and treatment of seizures, in order to titrate barbiturate therapy, as an indicator of cerebral ischemia, and to provide information regarding prognosis. Seizures are a well known complication of TBI, and can contribute to ongoing secondary brain injury (Claassen et al. 2004; Vespa et al. 1999). The incidence of electrographic seizures in severely head injured patients has been reported at 22-33\%, with more than half of these events being clinically silent (Vespa et al. 1999; Ronne-Engstrom \& Winkler 2006). Moreover, investigators utilizing intracortical electroencephalography report recording several seizures which were occult on simultaneous scalp EEG (Waziri et al. 2009). Seizures are both more likely and more difficult to detect in comatose patients, suggesting that these patients are most likely to benefit from continuous EEG (cEEG) monitoring (Claassen et al. 2004). Early post-traumatic seizures have been associated with adverse physiological events, including elevation of intracranial pressure and an increase in the lactate to pyruvate ratio (Vespa et al. 2007). There is no clear association between isolated post-traumatic seizures and increased mortality; however, case series suggest that posttraumatic status epilepticus carries a high risk of death (Vespa et al. 1999; Bratton et al. 2007). Although most investigators advocate treatment of early post-traumatic seizures as a means for reducing secondary brain injury, it remains to be determined if this intervention improves patient outcome. 


\subsubsection{Cerebral blood flow and brain tissue oxygenation}

The recognition of cerebral ischemia as a major contributing factor to secondary brain injury has generated considerable interest in measurement of cerebral perfusion in head injured patients. A number of imaging techniques, including transcranial Doppler ultrasound, xenon-enhanced CT, CT perfusion imaging, perfusion weighted MRI, and positron emitted tomography are available to evaluate cerebral perfusion. Using these techniques, investigators have demonstrated that cerebral blood flow following head trauma follows three distinct hemodynamic phases: initial hypoperfusion, accompanied by reduced cerebral metabolic rate of oxygen $\left(\mathrm{CMRO}_{2}\right)$; subsequent hyperemia, without an associated increase in $\mathrm{CMRO}_{2}$, which may be associated with intracranial hypertension; followed by a period in which cerebral blood flow (CBF) may be reduced secondary to vasospasm (Martin et al. 1997). However, the physiological and pathophysiological significance of these phases has been debated, and significant regional variation of cerebral perfusion is present (Wintermark et al. 2004). As discussed previously, cerebral perfusion can be significantly affected by systemic factors that impact the MAP and the CPP; the magnitude of this effect is dependent upon the individual's autoregulatory status (Czosnyka et al. 1998; Howells et al. 2005). Furthermore, the reports of the incidence and significance of cerebral vasospasm after trauma are variable, and likely are affected by the mechanism of injury (Martin et al. 1997; Zubkov et al. 2000). MR, CT, and PET based imaging techniques provide information regarding cerebral perfusion over large regions of the brain parenchyma, but for the most part the data obtained is useful only for a single time point. Transcranial Doppler can be performed for extended periods of time, but it is limited to the evaluation of the large vessels surrounding the Circle of Willis, and image quality is highly operator-dependent. More recently, parenchymal monitors have been used to provide a continuous measurement of cerebral blood flow in a specific, small region of tissue using thermal diffusion. This device is placed in the perilesional white matter via a burr hole in the skull. Use of CBF monitoring is currently employed in some centers and may provide a method for continuous assessment of cerebrovascular autoregulation in the future (Rosenthal et al. 2011).

In addition to CBF, brain oxygenation is often used as an indicator of cerebral ischemia. For decades, brain oxygenation could be assessed only indirectly, by intermittent sampling of the jugular venous blood. However, in the 1990s, a fiber-optic catheter which permitted continuous assessment of jugular venous oxygen saturation $\left(\mathrm{SjvO}_{2}\right)$ became available (Ritter et al. 1996). $\mathrm{SjvO}_{2}$ provides a global measure of cerebral oxygenation and can permit early detection of cerebral ischemia. Studies have shown that jugular venous desaturations (< $50 \%$ ) are correlated with poor outcome, especially if prolonged and/or recurrent (Gopinath et al. 1994). However, cerebral metabolism in TBI demonstrates regional heterogeneity, and a global measure such as $\mathrm{SjvO}_{2}$ may not permit detection of focal regions of ischemia (Valadka et al. 2000). More recently, intraparenchymal monitors have become available for the purpose of monitoring local brain tissue oxygen tension $\left(\mathrm{PbrO}_{2}\right)$. These monitors are typically inserted in normal-appearing brain tissue adjacent to a focal lesion, or in the right frontal region in the setting of diffuse axonal injury. As with $\mathrm{SjvO}_{2}$ monitoring, episodes of desaturation detected by $\mathrm{PbrO}_{2}$ monitoring have been shown to correlate with increased mortality (Stiefel et al. 2005). The critical value appears to be approximately $15 \mathrm{mmHg}$, though some clinicians prefer a treatment threshold of $20 \mathrm{mmHg}$ (Bratton et al. 2007). Various investigators have studied the relationships between $\mathrm{PbrO}_{2}$ and more conventional clinical parameters. In particular, positive correlations have been described between $\mathrm{PbrO}_{2}$ and various determinants of oxygen supply to the $\mathrm{CNS}$, including $\mathrm{FiO}_{2}, \mathrm{PaO}_{2}, \mathrm{CPP}$, and 
hemoglobin concentration (Stiefel et al. 2005). However, studies using PET imaging and monitoring of the arteriovenous oxygen tension difference have provided evidence that barriers to local oxygen diffusion, rather than determinants of oxygen supply, are significant determinants of $\mathrm{PbrO}_{2}$ (Rosenthal et al. 2008; Bratton et al. 2007).

A drop in cerebral oxygenation (as measured by $\mathrm{PbrO}_{2}$ or $\mathrm{SjvO}_{2}$ ) should prompt an investigation for an underlying cause, such subclinical seizures; an expanding mass lesion; suboptimal CPP; or systemic derangements such as hypotension or worsening lung function. The two monitoring methods are often complementary. For instance, $\mathrm{PbrO}_{2}$ is more sensitive to changes in the arterial oxygen content, and would be more likely to signal the expansion of a nearby contusion (Valadka et al. 2000). Cerebral oxygen desaturation can be successfully treated using measures designed to augment oxygen delivery, such as optimizing the CPP, increasing the fraction of inspired oxygen $\left(\mathrm{FiO}_{2}\right)$, and transfusion of red blood cells depending upon the patient's specific clinical characteristics; however, these interventions carry some risk. Normobaric hyperoxia has been shown to improve $\mathrm{PbrO}_{2}$ as well as some other markers of brain metabolism, but prolonged use exposes the patient to the risk of oxygen toxicity (Tisdall et al. 2008). Similarly, the optimal transfusion threshold for brain injured patients has yet to be determined, and injudicious use of blood products carries the risk of transfusion related lung injury, as well as other potential complications. A recent trial of 70 patients reported that a group of patients with severe TBI who received $\mathrm{PbrO}_{2}$ guided therapy (goal $>20 \mathrm{mmHg}$ ) demonstrated improved mortality and better functional outcomes than those managed using traditional ICP $(<20 \mathrm{mmHg})$ and CPP goals (> $60 \mathrm{mmHg}$ )(Spiotta et al. 2010). However, this trial relied on historical controls, and the authors did not report on the incidence of ARDS or other medical complications in either cohort. A multicenter randomized controlled trial addressing the use of $\mathrm{PbrO}_{2}$ monitoring in severe TBI is currently underway.

\section{Surgical management}

Surgical intervention is indicated in TBI for control of intracranial hypertension or restoring integrity of structures covering the brain as in compound injuries. High ICP, following TBI, can result from a focal intracranial hematoma or diffuse brain swelling. "Moderate" sized contusion hematomas can present the surgeon with a dilemma about whether to operate or observe the patient. Presence of alcohol or drugs on board can further compound the situation. Close clinical observation, ICP monitoring, and a follow-up head CT scan can help to guide the therapy, but ultimately surgeon's experience and clinical judgment plays a crucial role in decision making.

Evidence based guidelines are available to help with decision-making (Bullock et al. 2006, 2006; Bullock et al. 2006, 2006, 2006). Any mass lesion with progressive neurological decline referable to the lesion should be operated upon. A supratentorial lesion with a midline shift of $5 \mathrm{~mm}$ or more and effacement of the basal cisterns, and a posterior fossa lesion with compression or distortion of fourth ventricle or effacement of basal cisterns or obstructive hydrocephalus in patients with GCS of 8 or less should be evacuated. Epidural hematomas (EDH) larger than $30 \mathrm{~cm}^{3}$ and subdural hematomas greater than $10 \mathrm{~mm}$ in thickness or causing more than $5 \mathrm{~mm}$ of midline shift should be evacuated, independent of the GCS. An EDH less than $30 \mathrm{~cm}^{3}$, and less than $15 \mathrm{~mm}$ in maximal thickness, and with less than $5 \mathrm{~mm}$ midline shift, in a patient with a GCS of 9 or more without a focal deficit, can be managed non-surgically with close monitoring and repeat CT scans. Frontal or temporal lobe 
contusions greater than $20 \mathrm{~cm}^{3}$ associated with midline shift of $5 \mathrm{~mm}$ or more, in patients with GCS of 6 to 8 or any parenchymal lesion greater than $50 \mathrm{~cm}^{3}$ should be operated upon. An open (compound) cranial fracture depressed greater than the thickness of cranium should be operated upon to prevent infection. An open (compound) depressed fracture may be treated non surgically if it is not depressed more than $1 \mathrm{~cm}$, there is no dural penetration, no intracranial mass lesion, no frontal sinus involvement, no pneumocephalus, no cosmetic deformity, and no wound contamination or infection.

Decompressive craniectomy (DC) is being increasingly used for patients with severe diffuse TBI and medically refractory intracranial hypertension (Ahmad \& Bullock 2011). DC is effective in reducing the ICP and increasing the survival, but has not been shown to improve long term neurological outcome( $\mathrm{Li}$, Timofeev et al. 2010). In fact, there is strong evidence to suggest that DC in patients with severe TBI (GCS 3-8) with medically refractory intracranial hypertension is associated with a worse neurological outcome at 6 months after injury compared to similar patients who were treated with controlled ventilation, mannitol, hypertonic saline, external ventricular drainage, mild hypothermia and barbiturates(Cooper et al. 2011). DC for treatment of medically refractory intracranial hypertension, in severe diffuse TBI, is discouraged till parameters other than ICP control are available, to gauge the success of therapy (Marion 2011).This procedure can still be an effective therapy in very select group of patients such as those undergoing craniotomy for intracranial hematoma (particularly SDH) with significant brain swelling. Unwarranted use of DC may prove counterproductive in terms of neurological recovery in patients with severe TBI.

\section{Future directions}

\subsection{Microdialysis}

Microdialysis is an invasive monitoring technique which allows sampling of the extracellular fluid within the brain parenchyma in order to test for a variety of substances. Although a wide variety of substances can be analyzed successfully, glucose, lactate, pyruvate, glycerol, and glutamate are the most commonly employed. Glycerol is monitored primarily as a marker of membrane breakdown, whereas glucose, lactate, pyruvate, and the lactate/pyruvate ratio are used as markers of cerebral energy metabolism. The lactate/pyruvate ratio, in particular, is often employed as an indicator of the brain redox state and an early sign of focal ischemia. Microdialysis probes are usually placed in the frontal white matter in patients with diffuse brain injury, or in the pericontusional tissue in patients with focal radiographic abnormalities (Bellander et al. 2004). Although cerebral microdialysis has been widely used in animal studies for more than 30 years, its use in clinical practice is limited primarily to large academic centers where it is generally used in conjunction with other monitoring devices to provide an early indicator of evolving secondary brain injury. For instance, in cases of cerebral ischemia, the lacate/pyruvate ratio increases markedly, whereas the glucose level declines to near zero. These findings have been shown to correlate with $\mathrm{SjVO}_{2}$ and $\mathrm{PbrO}_{2}$ measurements, as well as the oxygen extraction fraction as measured by PET (Robertson et al. 1995; Valadka et al. 1998; Hutchinson et al. 2002). When used in conjunction with CPP and ICP monitoring, microdialysis may have a role in early detection of focal (as opposed to global) pathological processes, such as vasospasm or expanding contusions (Valadka \& Robertson 2007; Hillered, Vespa, \& Hovda 2005). 
The data acquired by centers that utilize microdialysis routinely provides considerable insight into the pathophysiology of secondary brain injury in this population. For instance, Vespa et al. have reported persistently low glucose levels in cerebral microdialysate in the first 50 hours following brain injury in patients with poor outcome, which was unrelated to cerebral ischemia (Vespa et al. 2003). This may reflect a disorder of energy metabolism related to ongoing brain injury in patients with severe TBI. Work from the same group has demonstrated that intensive insulin therapy, as practiced in many surgical ICUs, often results in evidence of metabolic stress in patients with TBI (Vespa et al. 2006). Investigators studying the relationship between $\mathrm{CPP}$ on cerebral glucose metabolism have noted significant increases in the lactate/pyruvate ratio at CPPs less than $50 \mathrm{mmHg}$ which were confined to perilesional tissue. This work would seem to support the contention that susceptibility to ischemic insult is greater in a region of "tissue at risk" adjacent to contused brain (Nordstrom et al. 2003). Data on hyperventilated patients have been conflicting, with some studies reporting no effect (Letarte et al. 1999). In contrast, another study demonstrated that increased glutamate and lactate/pyruvate ratio could be demonstrated in TBI patients hyperventilated within 36 hours of injury, though these changes were seen much less commonly at later time points (Marion et al. 2002). This observation reinforces the hypothesis that sustained hyperventilation is particularly detrimental in the early stages following TBI.

Microdialysis data has also been used to investigate the physiological effects of various therapeutic interventions. Hyperbaric oxygen therapy has been shown to result in a reproducible decrease in lactate and lactate/pyruvate ratio, which was accompanied by improvements in cerebral blood flow, $\mathrm{CMRO}_{2}$, and ICP (Rockswold et al. 2010). Similarly, microdialysis has been used to investigate the effect of barbiturates and propofol on cerebral energy metabolism. Thiopental coma was shown to reduce lactate in a small number of TBI patients, suggesting reduced anaerobic metabolism (Goodman et al. 1996). In contrast, propofol was not shown to have any significant effect on lactate, pyruvate, or glucose concentrations even when titrated to burst suppression (Johnston et al. 2003). Although both studies involved small numbers of patients, this would seem to suggest that barbiturates are more effective for the prevention of secondary brain injury.

\subsection{Biomarkers}

One of the major goals of ongoing research in TBI is the identification of reliable biomarkers. The ideal biomarker would enable early diagnosis of underlying brain injury, provide an early indicator of secondary brain injury, and enable clinicians to monitor the patient's response to therapy. Conceivably, use of a variety of biomarkers specific to different tissue types or mechanisms of injury may help to guide therapy and provide insight into ongoing pathophysiology. Over the past 40 years, a variety of candidate molecules have been evaluated in both clinical settings and in animal models. Perhaps the most widely studied is $\mathrm{S} 100 \mathrm{~B}$, a calcium-binding protein that is found in astrocytes. S100B has a half-life of $<60 \mathrm{~min}$ in serum; consequently, elevated levels are unlikely to persist for more than 24 hours in the absence of severe TBI (Berger 2006). This protein can be quantified in the serum and in the CSF; the peak serum levels appear to occur roughly 48 hours after the peak CSF concentration is reached (Petzold et al. 2003). Elevated levels of S100B have been shown to correlate with poor outcome, contusion volume, and (inversely) with certain quality of life measures (Raabe et al. 1998; Woertgen, Rothoerl, \& Brawanski 2002). Unfortunately, the 
time course of S100B release, the dynamics of transport across the blood-brain-barrier, and the patho- physiological implications of elevated S100B levels remain to be determined (Kleindienst et al. 2010). Other candidate biomarkers associated with outcome in TBI patients include neuron specific enlace, a cytoplasm protein found in neuronal tissue, and glial fibrillary acidic protein (GFAP), an intermediate filament protein found in astrocytes (Vos et al. 2004) GFAP, in particular, has been shown to correlate with CT findings and with outcome in trauma patients (Lumpkins et al. 2008; Nylen et al. 2006). Although no large scale studies are available, some investigators suggest that GFAP may prove to be more sensitive than neuron-specific enolase (NSE) or S100B, due to the lack of extracerebral sources (Honda et al. 2010).

Whereas NSE, S100B, and GFAP are markers of cellular breakdown, certain other candidate biomarkers serve as indicators of ongoing pathophysiological processes. For instance, diffuse axonal injury is characterized pathologically by axonal degradation, which is associated with the breakdown of axonal microtubules. This results in the release of microtubule-associated protein tau, which is cleaved into fragments which are known as cleaved-tau (C-tau) ( $\mathrm{Li}$, Li et al. 2010). The presence of C-tau in the CSF has been found to be a sensitive indicator of diffuse axonal injury, and levels correlate inversely with clinical improvement (Zemlan et al. 1999). Other putative biomarkers have the potential to allow investigators to differentiate between cell death related to apoptosis as opposed to necrosis. The alpha-II spectrin protein, for example, is a component of the axonal cytoskeleton which is cleaved by enzymes involved in both cellular necrosis (caspase-3) and apoptosis (calpain 1 and 2). Western blot analysis of the alpha-II spectrin breakdown products present in a given sample can therefore provide insight into the predominant mechanism of cellular loss ( $\mathrm{Li}, \mathrm{Li}$ et al. 2010). Preliminary studies using alpha-II spectrin breakdown products in humans have demonstrated that necrosis, mediated by calpain, is the predominant mechanism involved in acute DAI, suggesting that calpain inhibitors may be a potential therapeutic target (Brophy et al. 2009).

\subsection{Pharmacotherapy}

A major factor contributing to intractable intracranial hypertension following severe TBI is cerebral edema. Both cytotoxic and vasogenic edema contribute to post traumatic cerebral edema (Barzo et al. 1997). Therapeutic interventions directed at mediators of cerebral edema offer potential treatment options for TBI. Aquaporins (AQPs) are integral membrane proteins that form pores in membranes of mammalian cells, and play an important role in development and resolution of cerebral edema (Pasantes-Morales \& Cruz-Rangel 2010). AQPs modulation offers a potential therapeutic intervention to prevent or treat brain swelling (Manley et al. 2000; Papadopoulos \& Verkman 2008; Taya et al. 2008). Matrix metalloproteinases (MMPs) are zinc dependent endopeptidases involved in the process of tissue remodeling following brain injury from stroke or trauma. MMPs are upregulated following TBI, causing disruption of BBB and cerebral edema in the early phase, followed by neurogenesis and neurovascular remodeling in the later stages of recovery. Thus selective therapeutic blocking of the detrimental effects in the early phase offers the possibility of preventing cerebral edema without disrupting the later reparative phase (Donkin \& Vink 2010). A group of neuropeptides released from sensory neurons have been implicated in neurogenic inflammation. Neurogenic inflammation that includes vasodilation, plasma extravasation and neuronal hypersensitivity, has been shown to play a role in the 
development of post traumatic cerebral edema. Therapeutic inhibition of neurogenic inflammation offers another potential target to prevent cerebral edema after TBI (Donkin \& Vink 2010). Progesterone is another agent with potential therapeutic role in the management of TBI. Progesterone receptors are distributed throughout the central nervous system, and the steroid has neuroprotective properties. Progesterone decreases brain edema, attenuates free radicals and reduces neuronal loss in TBI animal model. There is class II evidence to suggest it may improve neurologic outcome in patients with TBI (Junpeng, Huang, \& Qin 2011).

\section{Conclusion}

TBI is a serious disorder with significant morbidity, mortality and economic implications. It is a dynamic process, and timely intervention can prevent progression of neurological decline. Foundation of acute care is built upon prompt resuscitation and transport from the site of accident to a tertiary care facility, appropriate imaging, and intensive monitoring focused on minimization and prevention of secondary damage. Considerable progress has been made in understanding the physiology of ICP and treatment of intracranial hypertension, but control of ICP does not always translate into good neurological outcome. Better understanding of pathophysiology, identification of newer parameters of brain function, and development of innovative therapeutic modalities is required to improve the outcome from TBI.

\section{References}

Adams, J. H., Doyle, D., Ford, I., Gennarelli, T. A., Graham, D. I., \& McLellan, D. R. (1989). Diffuse axonal injury in head injury: definition, diagnosis and grading, Histopathology, Vol.15, No. 1, (Jul 1989), pp. 49-59, ISSN 0309-0167

Agnelli, G., Piovella, F., Buoncristiani, P., Severi, P., Pini, M., D'Angelo, A., Beltrametti, C., Damiani, M., Andrioli, G. C., Pugliese, R., Iorio, A., \& Brambilla, G. (1998). Enoxaparin plus compression stockings compared with compression stockings alone in the prevention of venous thromboembolism after elective neurosurgery, $N$ Engl J Med, Vol.339, No. 2, (Jul 9 1998), pp. 80-85, ISSN 0028-4793 (Print)

Ahmad, F. U., \& Bullock, R. (2011). Decompressive craniectomy for severe head injury, World Neurosurg, Vol.75, No. 3-4, (Mar-Apr 2011), pp. 451-453, ISSN 1878-8750

Alzaga, A. G., Cerdan, M., \& Varon, J. (2006). Therapeutic hypothermia, Resuscitation, Vol.70, No. 3, (Sep 2006), pp. 369-380, ISSN 0300-9572

Badjatia, N., Carney, N., Crocco, T. J., Fallat, M. E., Hennes, H. M., Jagoda, A. S., Jernigan, S., Letarte, P. B., Lerner, E. B., Moriarty, T. M., Pons, P. T., Sasser, S., Scalea, T., Schleien, C. L., \& Wright, D. W. (2008). Guidelines for prehospital management of traumatic brain injury 2nd edition, Prehosp Emerg Care, Vol.12 Suppl 1, No., 2008), pp. S1-52, ISSN 1545-0066

Badjatia, N., Strongilis, E., Gordon, E., Prescutti, M., Fernandez, L., Fernandez, A., Buitrago, M., Schmidt, J. M., Ostapkovich, N. D., \& Mayer, S. A. (2008). Metabolic impact of shivering during therapeutic temperature modulation: the Bedside Shivering Assessment Scale, Stroke, Vol.39, No. 12, (Dec 2008), pp. 3242-3247, ISSN 1524-4628

Barzo, P., Marmarou, A., Fatouros, P., Hayasaki, K., \& Corwin, F. (1997). Contribution of vasogenic and cellular edema to traumatic brain swelling measured by diffusion- 
weighted imaging, J Neurosurg, Vol.87, No. 6, (Dec 1997), pp. 900-907, ISSN 00223085

Bellander, B. M., Cantais, E., Enblad, P., Hutchinson, P., Nordstrom, C. H., Robertson, C., Sahuquillo, J., Smith, M., Stocchetti, N., Ungerstedt, U., Unterberg, A., \& Olsen, N. V. (2004). Consensus meeting on microdialysis in neurointensive care, Intensive Care Med, Vol.30, No. 12, (Dec 2004), pp. 2166-2169, ISSN 0342-4642

Berger, R. P. (2006). The use of serum biomarkers to predict outcome after traumatic brain injury in adults and children, J Head Trauma Rehabil, Vol.21, No. 4, (Jul-Aug 2006), pp. 315-333, ISSN 0885-9701

Bernard, S. A., \& Buist, M. (2003). Induced hypothermia in critical care medicine: a review, Crit Care Med, Vol.31, No. 7, (Jul 2003), pp. 2041-2051, ISSN 0090-3493 (Print)

Bernard, S. A., Gray, T. W., Buist, M. D., Jones, B. M., Silvester, W., Gutteridge, G., \& Smith, K. (2002). Treatment of comatose survivors of out-of-hospital cardiac arrest with induced hypothermia, N Engl J Med, Vol.346, No. 8, (Feb 21 2002), pp. 557-563, ISSN 1533-4406

Bhardwaj, Anish. (2007). Osmotherapy in neurocritical care, Current Neurology and Neuroscience Reports, Vol.7, No., 2007), pp. 513-521

Bratton, S. L., Chestnut, R. M., Ghajar, J., McConnell Hammond, F. F., Harris, O. A., Hartl, R., Manley, G. T., Nemecek, A., Newell, D. W., Rosenthal, G., Schouten, J., Shutter, L., Timmons, S. D., Ullman, J. S., Videtta, W., Wilberger, J. E., \& Wright, D. W. (2007). Guidelines for the management of severe traumatic brain injury. I. Blood pressure and oxygenation, J Neurotrauma, Vol.24 Suppl 1, No., 2007), pp. S7-13, ISSN 0897-7151

Bratton, S. L., Chestnut, R. M., Ghajar, J., McConnell Hammond, F. F., Harris, O. A., Hartl, R., Manley, G. T., Nemecek, A., Newell, D. W., Rosenthal, G., Schouten, J., Shutter, L., Timmons, S. D., Ullman, J. S., Videtta, W., Wilberger, J. E., \& Wright, D. W. (2007). Guidelines for the management of severe traumatic brain injury. V. Deep vein thrombosis prophylaxis, J Neurotrauma, Vol.24 Suppl 1, No., 2007), pp. S32-36, ISSN 0897-7151

Bratton, S. L., Chestnut, R. M., Ghajar, J., McConnell Hammond, F. F., Harris, O. A., Hartl, R., Manley, G. T., Nemecek, A., Newell, D. W., Rosenthal, G., Schouten, J., Shutter, L., Timmons, S. D., Ullman, J. S., Videtta, W., Wilberger, J. E., \& Wright, D. W. (2007). Guidelines for the management of severe traumatic brain injury. VI. Indications for intracranial pressure monitoring, J Neurotrauma, Vol.24 Suppl 1, No., 2007), pp. S37-44, ISSN 0897-7151

Bratton, S. L., Chestnut, R. M., Ghajar, J., McConnell Hammond, F. F., Harris, O. A., Hartl, R., Manley, G. T., Nemecek, A., Newell, D. W., Rosenthal, G., Schouten, J., Shutter, L., Timmons, S. D., Ullman, J. S., Videtta, W., Wilberger, J. E., \& Wright, D. W. (2007). Guidelines for the management of severe traumatic brain injury. VIII. Intracranial pressure thresholds, J Neurotrauma, Vol.24 Suppl 1, No., 2007), pp. S5558, ISSN 0897-7151

Bratton, S. L., Chestnut, R. M., Ghajar, J., McConnell Hammond, F. F., Harris, O. A., Hartl, R., Manley, G. T., Nemecek, A., Newell, D. W., Rosenthal, G., Schouten, J., Shutter, L., Timmons, S. D., Ullman, J. S., Videtta, W., Wilberger, J. E., \& Wright, D. W. (2007). Guidelines for the management of severe traumatic brain injury. X. Brain 
oxygen monitoring and thresholds, J Neurotrauma, Vol.24 Suppl 1, No., 2007), pp. S65-70, ISSN 0897-7151

Bratton, S. L., Chestnut, R. M., Ghajar, J., McConnell Hammond, F. F., Harris, O. A., Hartl, R., Manley, G. T., Nemecek, A., Newell, D. W., Rosenthal, G., Schouten, J., Shutter, L., Timmons, S. D., Ullman, J. S., Videtta, W., Wilberger, J. E., \& Wright, D. W. (2007). Guidelines for the management of severe traumatic brain injury. XIII. Antiseizure prophylaxis, J Neurotrauma, Vol.24 Suppl 1, No., 2007), pp. S83-86, ISSN 0897-7151

Bratton, S. L., Chestnut, R. M., Ghajar, J., McConnell Hammond, F. F., Harris, O. A., Hartl, R., Manley, G. T., Nemecek, A., Newell, D. W., Rosenthal, G., Schouten, J., Shutter, L., Timmons, S. D., Ullman, J. S., Videtta, W., Wilberger, J. E., \& Wright, D. W. (2007). Guidelines for the management of severe traumatic brain injury. XIV. Hyperventilation, J Neurotrauma, Vol.24 Suppl 1, No., 2007), pp. S87-90, ISSN 08977151

Bratton, S. L., Chestnut, R. M., Ghajar, J., McConnell Hammond, F. F., Harris, O. A., Hartl, R., Manley, G. T., Nemecek, A., Newell, D. W., Rosenthal, G., Schouten, J., Shutter, L., Timmons, S. D., Ullman, J. S., Videtta, W., Wilberger, J. E., \& Wright, D. W. (2007). Guidelines for the management of severe traumatic brain injury. XV. Steroids, J Neurotrauma, Vol.24 Suppl 1, No., 2007), pp. S91-95, ISSN 0897-7151

Brophy, G. M., Pineda, J. A., Papa, L., Lewis, S. B., Valadka, A. B., Hannay, H. J., Heaton, S. C., Demery, J. A., Liu, M. C., Tepas, J. J., 3rd, Gabrielli, A., Robicsek, S., Wang, K. K., Robertson, C. S., \& Hayes, R. L. (2009). alphaII-Spectrin breakdown product cerebrospinal fluid exposure metrics suggest differences in cellular injury mechanisms after severe traumatic brain injury, J Neurotrauma, Vol.26, No. 4, (Apr 2009), pp. 471-479, ISSN 1557-9042

Bullock, M. R., Chesnut, R., Ghajar, J., Gordon, D., Hartl, R., Newell, D. W., Servadei, F., Walters, B. C., \& Wilberger, J. (2006). Surgical management of depressed cranial fractures, Neurosurgery, Vol.58, No. 3 Suppl, (Mar 2006), pp. S56-60; discussion Siiv, ISSN 1524-4040

Bullock, M. R., Chesnut, R., Ghajar, J., Gordon, D., Hartl, R., Newell, D. W., Servadei, F., Walters, B. C., \& Wilberger, J. (2006). Surgical management of posterior fossa mass lesions, Neurosurgery, Vol.58, No. 3 Suppl, (Mar 2006), pp. S47-55; discussion Si-iv, ISSN 1524-4040

Bullock, M. R., Chesnut, R., Ghajar, J., Gordon, D., Hartl, R., Newell, D. W., Servadei, F., Walters, B. C., \& Wilberger, J. (2006). Surgical management of traumatic parenchymal lesions, Neurosurgery, Vol.58, No. 3 Suppl, (Mar 2006), pp. S25-46; discussion Si-iv, ISSN 1524-4040

Bullock, M. R., Chesnut, R., Ghajar, J., Gordon, D., Hartl, R., Newell, D. W., Servadei, F., Walters, B. C., \& Wilberger, J. E. (2006). Surgical management of acute epidural hematomas, Neurosurgery, Vol.58, No. 3 Suppl, (Mar 2006), pp. S7-15; discussion Siiv, ISSN 1524-4040

Bullock, M. R., Chesnut, R., Ghajar, J., Gordon, D., Hartl, R., Newell, D. W., Servadei, F., Walters, B. C., \& Wilberger, J. E. (2006). Surgical management of acute subdural hematomas, Neurosurgery, Vol.58, No. 3 Suppl, (Mar 2006), pp. S16-24; discussion Si-iv, ISSN 1524-4040 
Chesnut, R. M., Marshall, L. F., Klauber, M. R., Blunt, B. A., Baldwin, N., Eisenberg, H. M., Jane, J. A., Marmarou, A., \& Foulkes, M. A. (1993). The role of secondary brain injury in determining outcome from severe head injury, J Trauma, Vol.34, No. 2, (Feb 1993), pp. 216-222, ISSN 0022-5282

Chiu, W. T., Yeh, K. H., Li, Y. C., Gan, Y. H., Chen, H. Y., \& Hung, C. C. (1997). Traumatic brain injury registry in Taiwan, Neurol Res, Vol.19, No. 3, (Jun 1997), pp. 261-264, ISSN 0161-6412

Claassen, J., Mayer, S. A., Kowalski, R. G., Emerson, R. G., \& Hirsch, L. J. (2004). Detection of electrographic seizures with continuous EEG monitoring in critically ill patients, Neurology, Vol.62, No. 10, (May 25 2004), pp. 1743-1748, ISSN 1526-632X

Clifton, G. L., Miller, E. R., Choi, S. C., Levin, H. S., McCauley, S., Smith, K. R., Jr., Muizelaar, J. P., Wagner, F. C., Jr., Marion, D. W., Luerssen, T. G., Chesnut, R. M., \& Schwartz, M. (2001). Lack of effect of induction of hypothermia after acute brain injury, N Engl J Med, Vol.344, No. 8, (Feb 22 2001), pp. 556-563, ISSN 0028-4793

Colantonio, A., Escobar, M. D., Chipman, M., McLellan, B., Austin, P. C., Mirabella, G., \& Ratcliff, G. (2008). Predictors of postacute mortality following traumatic brain injury in a seriously injured population, J Trauma, Vol.64, No. 4, (Apr 2008), pp. 876-882, ISSN 1529-8809

Cook, A. M., Peppard, A., \& Magnuson, B. (2008). Nutrition considerations in traumatic brain injury, Nutr Clin Pract, Vol.23, No. 6, (Dec-2009 Jan 2008), pp. 608-620, ISSN 0884-5336

Cooper, D. J., Rosenfeld, J. V., Murray, L., Arabi, Y. M., Davies, A. R., D'Urso, P., Kossmann, T., Ponsford, J., Seppelt, I., Reilly, P., \& Wolfe, R. (2011). Decompressive craniectomy in diffuse traumatic brain injury, $N$ Engl J Med, Vol.364, No. 16, (Apr 21 2011), pp. 1493-1502, ISSN 1533-4406

Corrigan, J. D., Selassie, A. W., \& Orman, J. A. (2010). The epidemiology of traumatic brain injury, J Head Trauma Rehabil, Vol.25, No. 2, (Mar-Apr 2010), pp. 72-80, ISSN 1550$509 x$

Czosnyka, M., Balestreri, M., Steiner, L., Smielewski, P., Hutchinson, P. J., Matta, B., \& Pickard, J. D. (2005). Age, intracranial pressure, autoregulation, and outcome after brain trauma, J Neurosurg, Vol.102, No. 3, (Mar 2005), pp. 450-454, ISSN 0022-3085

Czosnyka, M., Smielewski, P., Kirkpatrick, P., Piechnik, S., Laing, R., \& Pickard, J. D. (1998). Continuous monitoring of cerebrovascular pressure-reactivity in head injury, Acta Neurochir Suppl, Vol.71, No., 1998), pp. 74-77, ISSN 0065-1419 (Print)

Dewall, J. (2010). The ABCs of TBI. Evidence-based guidelines for adult traumatic brain injury care, JEMS, Vol.35, No. 4, (Apr 2010), pp. 54-61; quiz 63, ISSN 0197-2510

Dietrich, W. D., Alonso, O., Halley, M., \& Busto, R. (1996). Delayed posttraumatic brain hyperthermia worsens outcome after fluid percussion brain injury: a light and electron microscopic study in rats, Neurosurgery, Vol.38, No. 3, (Mar 1996), pp. 533541; discussion 541, ISSN 0148-396X

Dietrich, W. D., \& Bramlett, H. M. (2007). Hyperthermia and central nervous system injury, Prog Brain Res, Vol.162, No., 2007), pp. 201-217, ISSN 0079-6123

Diringer, M. N., \& Zazulia, A. R. (2004). Osmotic therapy: fact and fiction, Neurocrit Care, Vol.1, No. 2, 2004), pp. 219-233, ISSN 1541-6933 
Donkin, J. J., \& Vink, R. (2010). Mechanisms of cerebral edema in traumatic brain injury: therapeutic developments, Curr Opin Neurol, Vol.23, No. 3, (Jun 2010), pp. 293-299, ISSN 1473-6551

Dudley, R. R., Aziz, I., Bonnici, A., Saluja, R. S., Lamoureux, J., Kalmovitch, B., Gursahaney, A., Razek, T., Maleki, M., \& Marcoux, J. (2010). Early venous thromboembolic event prophylaxis in traumatic brain injury with low-molecular-weight heparin: risks and benefits, J Neurotrauma, Vol.27, No. 12, (Dec 2010), pp. 2165-2172, ISSN 1557-9042

Eisenberg, H. M., Frankowski, R. F., Contant, C. F., Marshall, L. F., \& Walker, M. D. (1988). High-dose barbiturate control of elevated intracranial pressure in patients with severe head injury, J Neurosurg, Vol.69, No. 1, (Jul 1988), pp. 15-23, ISSN 0022-3085

Eker, C., Asgeirsson, B., Grande, P. O., Schalen, W., \& Nordstrom, C. H. (1998). Improved outcome after severe head injury with a new therapy based on principles for brain volume regulation and preserved microcirculation, Crit Care Med, Vol.26, No. 11, (Nov 1998), pp. 1881-1886, ISSN 0090-3493

Enriquez, P., \& Bullock, R. (2004). Molecular and cellular mechanisms in the pathophysiology of severe head injury, Curr Pharm Des, Vol.10, No. 18, 2004), pp. 2131-2143, ISSN 1381-6128

Gabriel, E. J., Ghajar, J., Jagoda, A., Pons, P. T., Scalea, T., \& Walters, B. C. (2002). Guidelines for prehospital management of traumatic brain injury, J Neurotrauma, Vol.19, No. 1, (Jan 2002), pp. 111-174, ISSN 0897-7151 (Print)

Gennarelli, T. A. (1993). Mechanisms of brain injury, J Emerg Med, Vol.11 Suppl 1, No., 1993), pp. 5-11, ISSN 0736-4679

Goodman, J. C., Valadka, A. B., Gopinath, S. P., Cormio, M., \& Robertson, C. S. (1996). Lactate and excitatory amino acids measured by microdialysis are decreased by pentobarbital coma in head-injured patients, J Neurotrauma, Vol.13, No. 10, (Oct 1996), pp. 549-556, ISSN 0897-7151

Gopinath, S. P., Robertson, C. S., Contant, C. F., Hayes, C., Feldman, Z., Narayan, R. K., \& Grossman, R. G. (1994). Jugular venous desaturation and outcome after head injury, J Neurol Neurosurg Psychiatry, Vol.57, No. 6, (Jun 1994), pp. 717-723, ISSN 0022-3050

Graham, D. I., Adams, J. H., \& Gennarelli, T. A. (1988). Mechanisms of non-penetrating head injury, Prog Clin Biol Res, Vol.264, No., 1988), pp. 159-168, ISSN 0361-7742 (Print)

Gururaj G, Sastry Koeluri V, Chandramouli B, Subbakrishna D. 2004. Neurotrauma Registry in the NIMHANS. Bangalore, India: National Institute of Mental Health and Neurosciences.

Hartl, R., Gerber, L. M., Iacono, L., Ni, Q., Lyons, K., \& Ghajar, J. (2006). Direct transport within an organized state trauma system reduces mortality in patients with severe traumatic brain injury, J Trauma, Vol.60, No. 6, (Jun 2006), pp. 1250-1256; discussion 1256, ISSN 0022-5282

Hartl, R., Gerber, L. M., Ni, Q., \& Ghajar, J. (2008). Effect of early nutrition on deaths due to severe traumatic brain injury, J Neurosurg, Vol.109, No. 1, (Jul 2008), pp. 50-56, ISSN 0022-3085

Hays, A. N., Lazaridis, C., Neyens, R., Nicholas, J., Gay, S., \& Chalela, J. A. (2011). Osmotherapy: use among neurointensivists, Neurocrit Care, Vol.14, No. 2, (Apr 2011), pp. 222-228, ISSN 1556-0961 
Helmy, A., Vizcaychipi, M., \& Gupta, A. K. (2007). Traumatic brain injury: intensive care management, Br J Anaesth, Vol.99, No. 1, (Jul 2007), pp. 32-42, ISSN 0007-0912

Hiler, M., Czosnyka, M., Hutchinson, P., Balestreri, M., Smielewski, P., Matta, B., \& Pickard, J. D. (2006). Predictive value of initial computerized tomography scan, intracranial pressure, and state of autoregulation in patients with traumatic brain injury, $J$ Neurosurg, Vol.104, No. 5, (May 2006), pp. 731-737, ISSN 0022-3085 (Print)

Hillered, L., Vespa, P. M., \& Hovda, D. A. (2005). Translational neurochemical research in acute human brain injury: the current status and potential future for cerebral microdialysis, J Neurotrauma, Vol.22, No. 1, (Jan 2005), pp. 3-41, ISSN 0897-7151

Honda, M., Tsuruta, R., Kaneko, T., Kasaoka, S., Yagi, T., Todani, M., Fujita, M., Izumi, T., \& Maekawa, T. (2010). Serum glial fibrillary acidic protein is a highly specific biomarker for traumatic brain injury in humans compared with S-100B and neuronspecific enolase, J Trauma, Vol.69, No. 1, (Jul 2010), pp. 104-109, ISSN 1529-8809

Howells, T., Elf, K., Jones, P. A., Ronne-Engstrom, E., Piper, I., Nilsson, P., Andrews, P., \& Enblad, P. (2005). Pressure reactivity as a guide in the treatment of cerebral perfusion pressure in patients with brain trauma, J Neurosurg, Vol.102, No. 2, (Feb 2005), pp. 311-317, ISSN 0022-3085

Hutchinson, P. J., Gupta, A. K., Fryer, T. F., Al-Rawi, P. G., Chatfield, D. A., Coles, J. P., O'Connell, M. T., Kett-White, R., Minhas, P. S., Aigbirhio, F. I., Clark, J. C., Kirkpatrick, P. J., Menon, D. K., \& Pickard, J. D. (2002). Correlation between cerebral blood flow, substrate delivery, and metabolism in head injury: a combined microdialysis and triple oxygen positron emission tomography study, J Cereb Blood Flow Metab, Vol.22, No. 6, (Jun 2002), pp. 735-745, ISSN 0271-678X

Illievich, U. M., Zornow, M. H., Choi, K. T., Scheller, M. S., \& Strnat, M. A. (1994). Effects of hypothermic metabolic suppression on hippocampal glutamate concentrations after transient global cerebral ischemia, Anesth Analg, Vol.78, No. 5, (May 1994), pp. 905-911, ISSN 0003-2999

Jiang, J. Y., \& Yang, X. F. (2007). Current status of cerebral protection with mild-to-moderate hypothermia after traumatic brain injury, Curr Opin Crit Care, Vol.13, No. 2, (Apr 2007), pp. 153-155, ISSN 1070-5295

Jiang, J., Yu, M., \& Zhu, C. (2000). Effect of long-term mild hypothermia therapy in patients with severe traumatic brain injury: 1-year follow-up review of 87 cases, J Neurosurg, Vol.93, No. 4, (Oct 2000), pp. 546-549, ISSN 0022-3085

Johnston, A. J., Steiner, L. A., Chatfield, D. A., Coleman, M. R., Coles, J. P., Al-Rawi, P. G., Menon, D. K., \& Gupta, A. K. (2003). Effects of propofol on cerebral oxygenation and metabolism after head injury, Br J Anaesth, Vol.91, No. 6, (Dec 2003), pp. 781786, ISSN 0007-0912

Johnston, N. J., King, A. T., Protheroe, R., \& Childs, C. (2006). Body temperature management after severe traumatic brain injury: methods and protocols used in the United Kingdom and Ireland, Resuscitation, Vol.70, No. 2, (Aug 2006), pp. 254-262, ISSN 0300-9572

Junpeng, M., Huang, S., \& Qin, S. (2011). Progesterone for acute traumatic brain injury, Cochrane Database Syst Rev, No. 1, 2011), p. CD008409, ISSN 1469-493X

Juul, N., Morris, G. F., Marshall, S. B., \& Marshall, L. F. (2000). Intracranial hypertension and cerebral perfusion pressure: influence on neurological deterioration and outcome in 
severe head injury. The Executive Committee of the International Selfotel Trial, $J$ Neurosurg, Vol.92, No. 1, (Jan 2000), pp. 1-6, ISSN 0022-3085

Kassell, N. F., Hitchon, P. W., Gerk, M. K., Sokoll, M. D., \& Hill, T. R. (1980). Alterations in cerebral blood flow, oxygen metabolism, and electrical activity produced by high dose sodium thiopental, Neurosurgery, Vol.7, No. 6, (Dec 1980), pp. 598-603, ISSN 0148-396X

Kassell, N. F., Peerless, S. J., Drake, C. G., Boarini, D. J., \& Adams, H. P. (1980). Treatment of ischemic deficits from cerebral vasospasm with high dose barbiturate therapy, Neurosurgery, Vol.7, No. 6, (Dec 1980), pp. 593-597, ISSN 0148-396X

Kleindienst, A., Meissner, S., Eyupoglu, I. Y., Parsch, H., Schmidt, C., \& Buchfelder, M. (2010). Dynamics of S100B release into serum and cerebrospinal fluid following acute brain injury, Acta Neurochir Suppl, Vol.106, No., 2010), pp. 247-250, ISSN 00651419

Langlois JA, Rutland-Brown W, Thomas KE. 2006. Traumatic Brain Injury in the United States: Emergency Department Visits, Hospitalization and Deaths. Atlanta, GA: Centers for Disease Control and Prevention, National Center for Injury Control and Prevention.

Leker, R. R., \& Shohami, E. (2002). Cerebral ischemia and trauma-different etiologies yet similar mechanisms: neuroprotective opportunities, Brain Res Brain Res Rev, Vol.39, No. 1, (Jun 2002), pp. 55-73

Letarte, P. B., Puccio, A. M., Brown, S. D., \& Marion, D. W. (1999). Effect of hypocapnea on CBF and extracellular intermediates of secondary brain injury, Acta Neurochir Suppl, Vol.75, No., 1999), pp. 45-47, ISSN 0065-1419

Li, J., Li, X. Y., Feng, D. F., \& Pan, D. C. (2010). Biomarkers associated with diffuse traumatic axonal injury: exploring pathogenesis, early diagnosis, and prognosis, J Trauma, Vol.69, No. 6, (Dec 2010), pp. 1610-1618, ISSN 1529-8809

Li, L. M., Timofeev, I., Czosnyka, M., \& Hutchinson, P. J. (2010). Review article: the surgical approach to the management of increased intracranial pressure after traumatic brain injury, Anesth Analg, Vol.111, No. 3, (Sep 2010), pp. 736-748, ISSN 1526-7598

Liu-DeRyke, X., Collingridge, D. S., Orme, J., Roller, D., Zurasky, J., \& Rhoney, D. H. (2009). Clinical impact of early hyperglycemia during acute phase of traumatic brain

Liu, W. G., Qiu, W. S., Zhang, Y., Wang, W. M., Lu, F., \& Yang, X. F. (2006). Effects of selective brain cooling in patients with severe traumatic brain injury: a preliminary study, J Int Med Res, Vol.34, No. 1, (Jan-Feb 2006), pp. 58-64, ISSN 0300-0605

Lumpkins, K. M., Bochicchio, G. V., Keledjian, K., Simard, J. M., McCunn, M., \& Scalea, T. (2008). Glial fibrillary acidic protein is highly correlated with brain injury, J Trauma, Vol.65, No. 4, (Oct 2008), pp. 778-782; discussion 782-774, ISSN 1529-8809

Manley, G. T., Fujimura, M., Ma, T., Noshita, N., Filiz, F., Bollen, A. W., Chan, P., \& Verkman, A. S. (2000). Aquaporin-4 deletion in mice reduces brain edema after acute water intoxication and ischemic stroke, Nat Med, Vol.6, No. 2, (Feb 2000), pp. 159-163, ISSN 1078-8956

Marion, D. W. (2011). Decompressive craniectomy in diffuse traumatic brain injury, Lancet Neurol, Vol.10, No. 6, (Jun 2011), pp. 497-498, ISSN 1474-4465

Marion, D. W., Obrist, W. D., Carlier, P. M., Penrod, L. E., \& Darby, J. M. (1993). The use of moderate therapeutic hypothermia for patients with severe head injuries: a 
preliminary report, J Neurosurg, Vol.79, No. 3, (Sep 1993), pp. 354-362, ISSN 00223085

Marion, D. W., Penrod, L. E., Kelsey, S. F., Obrist, W. D., Kochanek, P. M., Palmer, A. M., Wisniewski, S. R., \& DeKosky, S. T. (1997). Treatment of traumatic brain injury with moderate hypothermia, $N$ Engl J Med, Vol.336, No. 8, (Feb 20 1997), pp. 540-546, ISSN 0028-4793

Marion, D. W., Puccio, A., Wisniewski, S. R., Kochanek, P., Dixon, C. E., Bullian, L., \& Carlier, P. (2002). Effect of hyperventilation on extracellular concentrations of glutamate, lactate, pyruvate, and local cerebral blood flow in patients with severe traumatic brain injury, Crit Care Med, Vol.30, No. 12, (Dec 2002), pp. 2619-2625, ISSN 0090-3493

Marshall, G. T., James, R. F., Landman, M. P., O'Neill, P. J., Cotton, B. A., Hansen, E. N., Morris, J. A., Jr., \& May, A. K. (2010). Pentobarbital coma for refractory intra-cranial hypertension after severe traumatic brain injury: mortality predictions and oneyear outcomes in 55 patients, J Trauma, Vol.69, No. 2, (Aug 2010), pp. 275-283, ISSN 1529-8809

Martin, N. A., Patwardhan, R. V., Alexander, M. J., Africk, C. Z., Lee, J. H., Shalmon, E., Hovda, D. A., \& Becker, D. P. (1997). Characterization of cerebral hemodynamic phases following severe head trauma: hypoperfusion, hyperemia, and vasospasm, $J$ Neurosurg, Vol.87, No. 1, (Jul 1997), pp. 9-19, ISSN 0022-3085

McIntyre, L. A., Fergusson, D. A., Hebert, P. C., Moher, D., \& Hutchison, J. S. (2003). Prolonged therapeutic hypothermia after traumatic brain injury in adults: a systematic review, JAMA, Vol.289, No. 22, (Jun 11 2003), pp. 2992-2999, ISSN 15383598

Meyer, M. J., Megyesi, J., Meythaler, J., Murie-Fernandez, M., Aubut, J. A., Foley, N., Salter, K., Bayley, M., Marshall, S., \& Teasell, R. (2010). Acute management of acquired brain injury part I: an evidence-based review of non-pharmacological interventions, Brain Inj, Vol.24, No. 5, 2010), pp. 694-705, ISSN 1362-301X

Meyer, M. J., Megyesi, J., Meythaler, J., Murie-Fernandez, M., Aubut, J. A., Foley, N., Salter, K., Bayley, M., Marshall, S., \& Teasell, R. (2010). Acute management of acquired brain injury part II: an evidence-based review of pharmacological interventions, Brain Inj, Vol.24, No. 5, 2010), pp. 706-721, ISSN 1362-301X (Electronic)

Mild therapeutic hypothermia to improve the neurologic outcome after cardiac arrest. (2002). N Engl J Med, Vol.346, No. 8, (Feb 21 2002), pp. 549-556, ISSN 1533-4406

Mishina, H., \& Yabuki, A. (1994). Relationship of cerebral blood flow, cerebral metabolism, and electroencephalography to outcome in acute experimental compression ischemia--barbiturate effects on delayed brain swelling, Neurol Med Chir (Tokyo), Vol.34, No. 6, (Jun 1994), pp. 345-352, ISSN 0470-8105

Muizelaar, J. P., van der Poel, H. G., Li, Z. C., Kontos, H. A., \& Levasseur, J. E. (1988). Pial arteriolar vessel diameter and $\mathrm{CO} 2$ reactivity during prolonged hyperventilation in the rabbit, J Neurosurg, Vol.69, No. 6, (Dec 1988), pp. 923-927, ISSN 0022-3085

Narayan, R. K., Michel, M. E., Ansell, B., Baethmann, A., Biegon, A., Bracken, M. B., Bullock, M. R., Choi, S. C., Clifton, G. L., Contant, C. F., Coplin, W. M., Dietrich, W. D., Ghajar, J., Grady, S. M., Grossman, R. G., Hall, E. D., Heetderks, W., Hovda, D. A., Jallo, J., Katz, R. L., Knoller, N., Kochanek, P. M., Maas, A. I., Majde, J., Marion, D. W., Marmarou, A., Marshall, L. F., McIntosh, T. K., Miller, E., Mohberg, N., 
Muizelaar, J. P., Pitts, L. H., Quinn, P., Riesenfeld, G., Robertson, C. S., Strauss, K. I., Teasdale, G., Temkin, N., Tuma, R., Wade, C., Walker, M. D., Weinrich, M., Whyte, J., Wilberger, J., Young, A. B., \& Yurkewicz, L. (2002). Clinical trials in head injury, J Neurotrauma, Vol.19, No. 5, (May 2002), pp. 503-557, ISSN 0897-7151

Nordstrom, C. H., Reinstrup, P., Xu, W., Gardenfors, A., \& Ungerstedt, U. (2003). Assessment of the lower limit for cerebral perfusion pressure in severe head injuries by bedside monitoring of regional energy metabolism, Anesthesiology, Vol.98, No. 4, (Apr 2003), pp. 809-814, ISSN 0003-3022

Norwood, S. H., Berne, J. D., Rowe, S. A., Villarreal, D. H., \& Ledlie, J. T. (2008). Early venous thromboembolism prophylaxis with enoxaparin in patients with blunt traumatic brain injury, J Trauma, Vol.65, No. 5, (Nov 2008), pp. 1021-1026; discussion 1026-1027, ISSN 1529-8809

Nurmohamed, M. T., van Riel, A. M., Henkens, C. M., Koopman, M. M., Que, G. T., d'Azemar, P., Buller, H. R., ten Cate, J. W., Hoek, J. A., van der Meer, J., van der Heul, C., Turpie, A. G., Haley, S., Sicurella, A., \& Gent, M. (1996). Low molecular weight heparin and compression stockings in the prevention of venous thromboembolism in neurosurgery, Thromb Haemost, Vol.75, No. 2, (Feb 1996), pp. 233-238, ISSN 0340-6245

Nylen, K., Ost, M., Csajbok, L. Z., Nilsson, I., Blennow, K., Nellgard, B., \& Rosengren, L. (2006). Increased serum-GFAP in patients with severe traumatic brain injury is related to outcome, J Neurol Sci, Vol.240, No. 1-2, (Jan 15 2006), pp. 85-91, ISSN 0022-510X

Ogden, Alfred T., Mayer, Stephan A., \& E. Sander Connolly, Jr. (2005). Hyperosmolar agents in neurosurgical practice: the evolving role of hypertonic saline Neurosurgery, Vol.57, No. 2, 2005), pp. 207-215

Papadopoulos, M. C., \& Verkman, A. S. (2008). Potential utility of aquaporin modulators for therapy of brain disorders, Prog Brain Res, Vol.170, No., 2008), pp. 589-601, ISSN 1875-7855

Pasantes-Morales, H., \& Cruz-Rangel, S. (2010). Brain volume regulation: osmolytes and aquaporin perspectives, Neuroscience, Vol.168, No. 4, (Jul 28 2010), pp. 871-884, ISSN 1873-7544

Patel, H. C., Bouamra, O., Woodford, M., King, A. T., Yates, D. W., \& Lecky, F. E. (2005). Trends in head injury outcome from 1989 to 2003 and the effect of neurosurgical care: an observational study, Lancet, Vol.366, No. 9496, (Oct 29-Nov 4 2005), pp. 1538-1544, ISSN 1474-547X

Petzold, A., Keir, G., Lim, D., Smith, M., \& Thompson, E. J. (2003). Cerebrospinal fluid (CSF) and serum S100B: release and wash-out pattern, Brain Res Bull, Vol.61, No. 3, (Aug 15 2003), pp. 281-285, ISSN 0361-9230

Povlishock, J. T., \& Wei, E. P. (2009). Posthypothermic rewarming considerations following traumatic brain injury, J Neurotrauma, Vol.26, No. 3, (Mar 2009), pp. 333-340, ISSN 1557-9042

Qiu, W., Shen, H., Zhang, Y., Wang, W., Liu, W., Jiang, Q., Luo, M., \& Manou, M. (2006). Noninvasive selective brain cooling by head and neck cooling is protective in severe traumatic brain injury, J Clin Neurosci, Vol.13, No. 10, (Dec 2006), pp. 9951000, ISSN 0967-5868 
Qiu, W., Zhang, Y., Sheng, H., Zhang, J., Wang, W., Liu, W., Chen, K., Zhou, J., \& Xu, Z. (2007). Effects of therapeutic mild hypothermia on patients with severe traumatic brain injury after craniotomy, J Crit Care, Vol.22, No. 3, (Sep 2007), pp. 229-235, ISSN 0883-9441

Raabe, A., Grolms, C., Keller, M., Dohnert, J., Sorge, O., \& Seifert, V. (1998). Correlation of computed tomography findings and serum brain damage markers following severe head injury, Acta Neurochir (Wien), Vol.140, No. 8, 1998), pp. 787-791; discussion 791-782, ISSN 0001-6268

Ritter, A. M., Gopinath, S. P., Contant, C., Narayan, R. K., \& Robertson, C. S. (1996). Evaluation of a regional oxygen saturation catheter for monitoring $\mathrm{SjvO} 2$ in head injured patients, J Clin Monit, Vol.12, No. 4, (Jul 1996), pp. 285-291, ISSN 0748-1977

Robertson, C. S. (2001). Management of cerebral perfusion pressure after traumatic brain injury, Anesthesiology, Vol.95, No. 6, (Dec 2001), pp. 1513-1517, ISSN 0003-3022

Robertson, C. S., Gopinath, S. P., Goodman, J. C., Contant, C. F., Valadka, A. B., \& Narayan, R. K. (1995). SjvO2 monitoring in head-injured patients, J Neurotrauma, Vol.12, No. 5, (Oct 1995), pp. 891-896, ISSN 0897-7151

Robertson, C. S., Valadka, A. B., Hannay, H. J., Contant, C. F., Gopinath, S. P., Cormio, M., Uzura, M., \& Grossman, R. G. (1999). Prevention of secondary ischemic insults after severe head injury, Crit Care Med, Vol.27, No. 10, (Oct 1999), pp. 2086-2095, ISSN 0090-3493

Rockswold, S. B., Rockswold, G. L., Zaun, D. A., Zhang, X., Cerra, C. E., Bergman, T. A., \& Liu, J. (2010). A prospective, randomized clinical trial to compare the effect of hyperbaric to normobaric hyperoxia on cerebral metabolism, intracranial pressure, and oxygen toxicity in severe traumatic brain injury, J Neurosurg, Vol.112, No. 5, (May 2010), pp. 1080-1094, ISSN 1933-0693

Ronne-Engstrom, E., \& Winkler, T. (2006). Continuous EEG monitoring in patients with traumatic brain injury reveals a high incidence of epileptiform activity, Acta Neurol Scand, Vol.114, No. 1, (Jul 2006), pp. 47-53, ISSN 0001-6314

Rosenthal, G., Hemphill, J. C., 3rd, Sorani, M., Martin, C., Morabito, D., Obrist, W. D., \& Manley, G. T. (2008). Brain tissue oxygen tension is more indicative of oxygen diffusion than oxygen delivery and metabolism in patients with traumatic brain injury, Crit Care Med, Vol.36, No. 6, (Jun 2008), pp. 1917-1924, ISSN 1530-0293

Rosenthal, G., Sanchez-Mejia, R. O., Phan, N., Hemphill, J. C., 3rd, Martin, C., \& Manley, G. T. (2011). Incorporating a parenchymal thermal diffusion cerebral blood flow probe in bedside assessment of cerebral autoregulation and vasoreactivity in patients with severe traumatic brain injury, J Neurosurg, Vol.114, No. 1, (Jan 2011), pp. 62-70, ISSN 1933-0693

Rosomoff, H. L., \& Holaday, D. A. (1954). Cerebral blood flow and cerebral oxygen consumption during hypothermia, Am J Physiol, Vol.179, No. 1, (Oct 1954), pp. 8588, ISSN 0002-9513

Sacks, G. S., Brown, R. O., Teague, D., Dickerson, R. N., Tolley, E. A., \& Kudsk, K. A. (1995). Early nutrition support modifies immune function in patients sustaining severe head injury, JPEN J Parenter Enteral Nutr, Vol.19, No. 5, (Sep-Oct 1995), pp. 387-392, ISSN 0148-6071

Schroder, M. L., Muizelaar, J. P., Bullock, M. R., Salvant, J. B., \& Povlishock, J. T. (1995). Focal ischemia due to traumatic contusions documented by stable xenon-CT and 
ultrastructural studies, J Neurosurg, Vol.82, No. 6, (Jun 1995), pp. 966-971, ISSN 0022-3085

Schwartz, M. L., Tator, C. H., Rowed, D. W., Reid, S. R., Meguro, K., \& Andrews, D. F. (1984). The University of Toronto head injury treatment study: a prospective, randomized comparison of pentobarbital and mannitol, Can J Neurol Sci, Vol.11, No. 4, (Nov 1984), pp. 434-440, ISSN 0317-1671

Schwarz, S., Georgiadis, D., Aschoff, A., \& Schwab, S. (2002). Effects of hypertonic (10\%) saline in patients with raised intracranial pressure after stroke, Stroke, Vol.33, No. 1, (Jan 2002), pp. 136-140, ISSN 1524-4628

Seelig, J. M., Becker, D. P., Miller, J. D., Greenberg, R. P., Ward, J. D., \& Choi, S. C. (1981). Traumatic acute subdural hematoma: major mortality reduction in comatose patients treated within four hours, N Engl J Med, Vol.304, No. 25, (Jun 18 1981), pp. 1511-1518, ISSN 0028-4793

Segatore, M. (1992). Fever after traumatic brain injury, J Neurosci Nurs, Vol.24, No. 2, (Apr 1992), pp. 104-109, ISSN 0888-0395

Selassie, A. W., Zaloshnja, E., Langlois, J. A., Miller, T., Jones, P., \& Steiner, C. (2008). Incidence of long-term disability following traumatic brain injury hospitalization, United States, 2003, J Head Trauma Rehabil, Vol.23, No. 2, (Mar-Apr 2008), pp. 123131, ISSN 0885-9701

Shiozaki, T., Sugimoto, H., Taneda, M., Yoshida, H., Iwai, A., Yoshioka, T., \& Sugimoto, T. (1993). Effect of mild hypothermia on uncontrollable intracranial hypertension after severe head injury, J Neurosurg, Vol.79, No. 3, (Sep 1993), pp. 363-368, ISSN 00223085

Shohami, E., Beit-Yannai, E., Horowitz, M., \& Kohen, R. (1997). Oxidative stress in closedhead injury: brain antioxidant capacity as an indicator of functional outcome, $J$ Cereb Blood Flow Metab, Vol.17, No. 10, (Oct 1997), pp. 1007-1019, ISSN 0271-678X

Sirvent, J. M., Torres, A., El-Ebiary, M., Castro, P., de Batlle, J., \& Bonet, A. (1997). Protective effect of intravenously administered cefuroxime against nosocomial pneumonia in patients with structural coma, Am J Respir Crit Care Med, Vol.155, No. 5, (May 1997), pp. 1729-1734, ISSN 1073-449X

Skandsen, T., Kvistad, K. A., Solheim, O., Strand, I. H., Folvik, M., \& Vik, A. (2010). Prevalence and impact of diffuse axonal injury in patients with moderate and severe head injury: a cohort study of early magnetic resonance imaging findings and 1-year outcome, J Neurosurg, Vol.113, No. 3, (Sep 2010), pp. 556-563, ISSN 19330693

Smith, A. L., Hoff, J. T., Nielsen, S. L., \& Larson, C. P. (1974). Barbiturate protection in acute focal cerebral ischemia, Stroke, Vol.5, No. 1, (Jan-Feb 1974), pp. 1-7, ISSN 0039-2499

Soares, H. D., Hicks, R. R., Smith, D., \& McIntosh, T. K. (1995). Inflammatory leukocytic recruitment and diffuse neuronal degeneration are separate pathological processes resulting from traumatic brain injury, J Neurosci, Vol.15, No. 12, (Dec 1995), pp. 8223-8233, ISSN 0270-6474

Spiotta, A. M., Stiefel, M. F., Gracias, V. H., Garuffe, A. M., Kofke, W. A., Maloney-Wilensky, E., Troxel, A. B., Levine, J. M., \& Le Roux, P. D. (2010). Brain tissue oxygen-directed management and outcome in patients with severe traumatic brain injury, $J$ Neurosurg, Vol.113, No. 3, (Sep 2010), pp. 571-580, ISSN 1933-0693 
Stein, S. C., Georgoff, P., Meghan, S., Mizra, K., \& Sonnad, S. S. (2010). 150 years of treating severe traumatic brain injury: a systematic review of progress in mortality, $J$ Neurotrauma, Vol.27, No. 7, (Jul 2010), pp. 1343-1353, ISSN 1557-9042

Stewart, L., Bullock, R., Rafferty, C., Fitch, W., \& Teasdale, G. M. (1994). Propofol sedation in severe head injury fails to control high ICP, but reduces brain metabolism, Acta Neurochir Suppl (Wien), Vol.60, No., 1994), pp. 544-546, ISSN 0065-1419

Stiefel, M. F., Spiotta, A., Gracias, V. H., Garuffe, A. M., Guillamondegui, O., MaloneyWilensky, E., Bloom, S., Grady, M. S., \& LeRoux, P. D. (2005). Reduced mortality rate in patients with severe traumatic brain injury treated with brain tissue oxygen monitoring, J Neurosurg, Vol.103, No. 5, (Nov 2005), pp. 805-811, ISSN 0022-3085

Tagliaferri, F., Compagnone, C., Korsic, M., Servadei, F., \& Kraus, J. (2006). A systematic review of brain injury epidemiology in Europe, Acta Neurochir (Wien), Vol.148, No. 3, (Mar 2006), pp. 255-268; discussion 268, ISSN 0001-6268 (Print)

Taya, K., Gulsen, S., Okuno, K., Prieto, R., Marmarou, C. R., \& Marmarou, A. (2008). Modulation of AQP4 expression by the selective V1a receptor antagonist, SR49059, decreases trauma-induced brain edema, Acta Neurochir Suppl, Vol.102, No., 2008), pp. 425-429, ISSN 0065-1419

Taylor, S. J., Fettes, S. B., Jewkes, C., \& Nelson, R. J. (1999). Prospective, randomized, controlled trial to determine the effect of early enhanced enteral nutrition on clinical outcome in mechanically ventilated patients suffering head injury, Crit Care Med, Vol.27, No. 11, (Nov 1999), pp. 2525-2531, ISSN 0090-3493

Tisdall, M. M., Tachtsidis, I., Leung, T. S., Elwell, C. E., \& Smith, M. (2008). Increase in cerebral aerobic metabolism by normobaric hyperoxia after traumatic brain injury, $J$ Neurosurg, Vol.109, No. 3, (Sep 2008), pp. 424-432, ISSN 0022-3085

Valadka, A. B., Furuya, Y., Hlatky, R., \& Robertson, C. S. (2000). Global and regional techniques for monitoring cerebral oxidative metabolism after severe traumatic brain injury, Neurosurg Focus, Vol.9, No. 5, 2000), p. e3, ISSN 1092-0684

Valadka, A. B., Goodman, J. C., Gopinath, S. P., Uzura, M., \& Robertson, C. S. (1998). Comparison of brain tissue oxygen tension to microdialysis-based measures of cerebral ischemia in fatally head-injured humans, J Neurotrauma, Vol.15, No. 7, (Jul 1998), pp. 509-519, ISSN 0897-7151

Valadka, A. B., \& Robertson, C. S. (2007). Surgery of cerebral trauma and associated critical care, Neurosurgery, Vol.61, No. 1 Suppl, (Jul 2007), pp. 203-220; discussion 220-201, ISSN 1524-4040

Ventilation with lower tidal volumes as compared with traditional tidal volumes for acute lung injury and the acute respiratory distress syndrome. The Acute Respiratory Distress Syndrome Network. (2000). N Engl J Med, Vol.342, No. 18, (May 4 2000), pp. 1301-1308, ISSN 0028-4793

Vespa, P., Boonyaputthikul, R., McArthur, D. L., Miller, C., Etchepare, M., Bergsneider, M., Glenn, T., Martin, N., \& Hovda, D. (2006). Intensive insulin therapy reduces microdialysis glucose values without altering glucose utilization or improving the lactate/pyruvate ratio after traumatic brain injury, Crit Care Med, Vol.34, No. 3, (Mar 2006), pp. 850-856, ISSN 0090-3493

Vespa, P. M., McArthur, D., O'Phelan, K., Glenn, T., Etchepare, M., Kelly, D., Bergsneider, M., Martin, N. A., \& Hovda, D. A. (2003). Persistently low extracellular glucose correlates with poor outcome 6 months after human traumatic brain injury despite 
a lack of increased lactate: a microdialysis study, J Cereb Blood Flow Metab, Vol.23, No. 7, (Jul 2003), pp. 865-877, ISSN 0271-678X

Vespa, P. M., Miller, C., McArthur, D., Eliseo, M., Etchepare, M., Hirt, D., Glenn, T. C., Martin, N., \& Hovda, D. (2007). Nonconvulsive electrographic seizures after traumatic brain injury result in a delayed, prolonged increase in intracranial pressure and metabolic crisis, Crit Care Med, Vol.35, No. 12, (Dec 2007), pp. 28302836, ISSN 0090-3493

Vespa, P. M., Nuwer, M. R., Nenov, V., Ronne-Engstrom, E., Hovda, D. A., Bergsneider, M., Kelly, D. F., Martin, N. A., \& Becker, D. P. (1999). Increased incidence and impact of nonconvulsive and convulsive seizures after traumatic brain injury as detected by continuous electroencephalographic monitoring, J Neurosurg, Vol.91, No. 5, (Nov 1999), pp. 750-760, ISSN 0022-3085

Vialet, R., Albanese, J., Thomachot, L., Antonini, F., Bourgouin, A., Alliez, B., \& Martin, C. (2003). Isovolume hypertonic solutes (sodium chloride or mannitol) in the treatment of refractory posttraumatic intracranial hypertension: $2 \mathrm{~mL} / \mathrm{kg} 7.5 \%$ saline is more effective than $2 \mathrm{~mL} / \mathrm{kg} \mathrm{20 \%}$ mannitol, Crit Care Med, Vol.31, No. 6, (Jun 2003), pp. 1683-1687, ISSN 0090-3493

Vos, P. E., Lamers, K. J., Hendriks, J. C., van Haaren, M., Beems, T., Zimmerman, C., van Geel, W., de Reus, H., Biert, J., \& Verbeek, M. M. (2004). Glial and neuronal proteins in serum predict outcome after severe traumatic brain injury, Neurology, Vol.62, No. 8, (Apr 27 2004), pp. 1303-1310, ISSN 1526-632X

Ward, J. D., Becker, D. P., Miller, J. D., Choi, S. C., Marmarou, A., Wood, C., Newlon, P. G., \& Keenan, R. (1985). Failure of prophylactic barbiturate coma in the treatment of severe head injury, J Neurosurg, Vol.62, No. 3, (Mar 1985), pp. 383-388, ISSN 00223085

Waziri, A., Claassen, J., Stuart, R. M., Arif, H., Schmidt, J. M., Mayer, S. A., Badjatia, N., Kull, L. L., Connolly, E. S., Emerson, R. G., \& Hirsch, L. J. (2009). Intracortical electroencephalography in acute brain injury, Ann Neurol, Vol.66, No. 3, (Sep 2009), pp. 366-377, ISSN 1531-8249

Weant, K. A., Martin, J. E., Humphries, R. L., \& Cook, A. M. (2010). Pharmacologic options for reducing the shivering response to therapeutic hypothermia, Pharmacotherapy, Vol.30, No. 8, (Aug 2010), pp. 830-841, ISSN 1875-9114

Wintermark, M., van Melle, G., Schnyder, P., Revelly, J. P., Porchet, F., Regli, L., Meuli, R., Maeder, P., \& Chiolero, R. (2004). Admission perfusion CT: prognostic value in patients with severe head trauma, Radiology, Vol.232, No. 1, (Jul 2004), pp. 211-220, ISSN 0033-8419

Woertgen, C., Rothoerl, R. D., \& Brawanski, A. (2002). Early S-100B serum level correlates to quality of life in patients after severe head injury, Brain Inj, Vol.16, No. 9, (Sep 2002), pp. 807-816, ISSN 0269-9052

Young, N., Rhodes, J. K., Mascia, L., \& Andrews, P. J. (2010). Ventilatory strategies for patients with acute brain injury, Curr Opin Crit Care, Vol.16, No. 1, (Feb 2010), pp. 45-52, ISSN 1531-7072

Zaloshnja, E., Miller, T., Langlois, J. A., \& Selassie, A. W. (2008). Prevalence of long-term disability from traumatic brain injury in the civilian population of the United States, 2005, J Head Trauma Rehabil, Vol.23, No. 6, (Nov-Dec 2008), pp. 394-400, ISSN 1550-509X 
Zemlan, F. P., Rosenberg, W. S., Luebbe, P. A., Campbell, T. A., Dean, G. E., Weiner, N. E., Cohen, J. A., Rudick, R. A., \& Woo, D. (1999). Quantification of axonal damage in traumatic brain injury: affinity purification and characterization of cerebrospinal fluid tau proteins, J Neurochem, Vol.72, No. 2, (Feb 1999), pp. 741-750, ISSN 00223042 


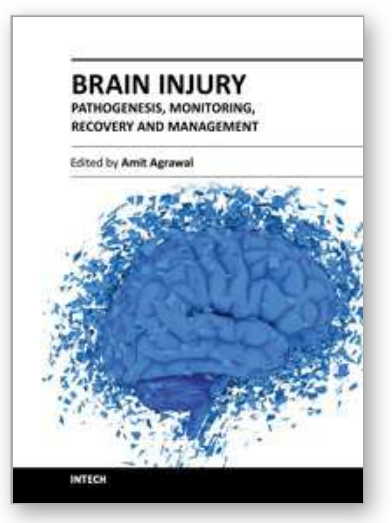

\author{
Brain Injury - Pathogenesis, Monitoring, Recovery and \\ Management \\ Edited by Prof. Amit Agrawal
}

ISBN 978-953-51-0265-6

Hard cover, 522 pages

Publisher InTech

Published online 23, March, 2012

Published in print edition March, 2012

The present two volume book "Brain Injury" is distinctive in its presentation and includes a wealth of updated information on many aspects in the field of brain injury. The Book is devoted to the pathogenesis of brain injury, concepts in cerebral blood flow and metabolism, investigative approaches and monitoring of brain injured, different protective mechanisms and recovery and management approach to these individuals, functional and endocrine aspects of brain injuries, approaches to rehabilitation of brain injured and preventive aspects of traumatic brain injuries. The collective contribution from experts in brain injury research area would be successfully conveyed to the readers and readers will find this book to be a valuable guide to further develop their understanding about brain injury.

\title{
How to reference
}

In order to correctly reference this scholarly work, feel free to copy and paste the following:

Angela N. Hays and Abhay K. Varma (2012). Traumatic Brain Injury - Acute Care, Brain Injury - Pathogenesis, Monitoring, Recovery and Management, Prof. Amit Agrawal (Ed.), ISBN: 978-953-51-0265-6, InTech, Available from: http://www.intechopen.com/books/brain-injury-pathogenesis-monitoring-recovery-andmanagement/traumatic-brain-injury-acute-care

\section{INTECH}

open science | open minds

\section{InTech Europe}

University Campus STeP Ri

Slavka Krautzeka 83/A

51000 Rijeka, Croatia

Phone: +385 (51) 770447

Fax: +385 (51) 686166

www.intechopen.com

\section{InTech China}

Unit 405, Office Block, Hotel Equatorial Shanghai

No.65, Yan An Road (West), Shanghai, 200040, China

中国上海市延安西路65号上海国际贵都大饭店办公楼405单元

Phone: +86-21-62489820

Fax: +86-21-62489821 
(C) 2012 The Author(s). Licensee IntechOpen. This is an open access article distributed under the terms of the Creative Commons Attribution 3.0 License, which permits unrestricted use, distribution, and reproduction in any medium, provided the original work is properly cited. 